PART 1

East Java 
Gerben Nooteboom - 9789004282988

Downloaded from Brill. come4/26/2023 11:42:53AM via free access 


\section{A Baseline of Desire \\ Rural Livelihoods, Inequality and Social Mobility}

The examples in the introduction show that the lives and living conditions of people are not stable, cannot be taken for granted and can change quickly. Over the course of one generation, some families have fallen from relative wealth to sheer poverty, while others were able to escape from poverty. Class alone does not determine one's future. Poverty and affluence are not fixed categories, and neither are friendships and other social ties.

To understand this fluidity, we need to study the interrelationships between agrarian structure, opportunities and bad luck, and individual and collective choices. The above-mentioned cases and questions reflect people in the relatively small world of the village. However, the lives of the villagers are not confined to the village: villagers are part of, and live within, a wider regional and national context. Villages are not isolated communities but interknit with the outside world through politics, the media, networks of kin, migration, trade and religion.

In this chapter, we look at the structural conditions of rural society in East Java, the baseline from which migrants depart. It first looks at the village of Krajan, the history of Madurese settlement in East Java and at the basic agrarian structure of Madurese East Java. We look at three aspects: rural livelihoods; access to resources; and inequality. Before doing so, we look at the history of Madurese migration to Krajan.

\section{Madurese Migration to East Java - a Short History}

The area between Besuki, Bondowoso and Jember was inhabited long before the official founding of Krajan, but these populations disappeared as a result of long periods of warfare prior to 1700 . There is archaeological evidence that the areas west and south of Jember were densely populated before and during the 16th century (Cribb 2000:43). These populations were almost entirely wiped out before Madurese settlers repopulated the areas.

In the mid-slope area around Krajan, there are also signs of earlier habitation. In the village itself, as in other places on the north slope of Mount Argopuro, graves, tombstones and holy places (keramat) are to found that originate from before the $17^{\text {th }}$ century, and which recall a more prosperous past. Archaeological remnants of Hindu settlements and holy places have been

(C) GERBEN NOOTEBOOM, 2015 | DOI 10.1163/9789004282988_003

This is an open access chapter distributed under the terms of the Creative Commons Attribution- 
found three kilometres north of Krajan and at the northern end of the Argopuro mountain (Gennep 1895, Veth 1903). In the village, many stories circulate of people who have found jewellery, pottery and other valuables in and around these old places. Some of the keramat are still in use as burial places, mosques have been built on others and some can be spotted as mounds or graveyards in the fields or have simply been demolished by villagers in search of valuables or wishing to extend their fields. ${ }^{1}$

Although Madura had Muslim rulers since 1527 (Ricklefs 1991:39), mainland East Java was under Hindu rule in the 16th century. Pasuruan was the only significant Islamic power in the Eastern Salient during the 16th century. There were numerous wars on the extreme southeast coast of Java during the 16th century between Pasuruan and Blambangan. In 1600-1601, the town of Blambangan was conquered by Pasuruan fighters (Ricklefs 1991:39-40). The area of Bondowoso - situated between these kingdoms - oscillated between Hindu and Pasuruan rule, and every now and then passing armies must have destroyed houses, fields and crops with resulting depopulation. ${ }^{2}$

In 1614, Sultan Agung of Mataram assaulted much of Java's northern coast, the Eastern Salient and Pasuruan; and again raided Pasuruan in 1616 and 1617 during the Trunojoyo revolt. In 1624, Sultan Agung subdued Madura. One of the strategies of Sultan Agung was to weaken the enemy through forced migration of large populations and the destruction of crops, food reserves and livestock in the area under attack (Ricklefs 1991:43).

These wars in the Eastern Salient led to huge devastation, starvation and epidemics in the area where Jember and Bondowoso are now situated. voc reports from 1625 (quoted in Ricklefs, 1991: 44) claim that two-thirds of the population died in some of the conflict areas. In 1633, more raids took place in the Eastern Salient including against Blambangan and Panarukan, which again led to huge devastation. After crushing the resistance of Pasuruan, Panarukan and Blambangan, the Eastern Salient remained the scene of several conflicts between Mataram and Balinese rulers until the end of the 17th century. By the beginning of the 18th century, none or only a few of the original people who had inhabited the areas around Pasurauan, Panarukan and Blambangan were left. ${ }^{3}$ The area was ripe for resettlement, and often undertaken by people from

1 These keramat and artefacts from graves are believed to possess magical powers and curses and only daredevils are inclined to open graves and demolish burial mounds (after giving a selamatan and lengthy fasting).

2 See for an overview: Cribb 2000:86-92.

3 They had died as a result of killings, starvation, deportation or epidemics caused by the wars between the kingdoms of Bali and Mataram. Passing armies of both central Javanese and 
Madura. The voc left the rule of these coastal areas of East Java to the Sultans of Sumenep, reflecting the already firm relationships between these areas. ${ }^{4}$ Such strong links with east Madura remain until the current day.

After 1740, the influence of the voc continued to grow on the north coast of Java, and several trading ports and fortifications were established. ${ }^{5}$ Slowly, the Dutch imposed a firm hegemony over this part of Java, peace was restored and the population again increased, mostly with Madurese people from the Sumenep area following the already established ties. The voc offered the empty lands of East Java to those Madurese soldiers who had fought for them.

Thus, Madurese migration into the interior of the Eastern uplands first started in the coastal area of Besuki after 1700. A century later, the whole northern coastal zone of residentie Besuki, and some of the inlands were almost completely, albeit still sparsely, populated by Madurese. After 1768, when the voc seized full control over the region, migration to Besuki from the overpopulated, dry and infertile island of Madura was actively encouraged by both Dutch and Madurese rulers, and more settlers started to move into the mainland of East Java (Tennekens 1963). ${ }^{6}$ A few decades later, the area was sufficiently important to link it to Daendeals' Great Mail Road (Jalan Raya Pos). The trunk road connecting Besuki and Panarukan with the rest of Java further added to the economic possibilities of the area. With the boom in agricultural commodity production in the second half of the 19th century, more Madurese came as settlers and labourers. Population pressure on the fertile coastline of Besuki was building at the end of the 19th century, increasing the size of towns and cities on the north coast including Pasuruan, Probolinggo, Besuki and Panarukan, and new land was needed (Suhartono, 1993; Tennekens, 1963:327).

Balinese - East Javanese origin had ruined the land between these kingdoms. As a result, the area of Bondowoso and Jember was virtually uninhabited at the beginning of the 18th century except for the areas around Besuki, Panarukan and Banyuwangi where new migrants probably from Madura - had settled Tennekens (1967:323). It is also likely that some of the original Hindu communities survived in the higher mountains, as Hefner Hefner (1990:57) describes for the Tengger area. In the cities and towns of the north coast, the influence of traders and rulers from Madura increased.

4 For an elaborate account of rule, trade, commercialisation and global connections see: Kwee Hui Kian's (2006) well documented book on the political economy of Java's Northeast coast, c. $1740-1800$.

5 In 1743, Mataram seceded the Eastern Salient to voc rule, but it would not be until 1767-68 that they defeated the 'Surapati rebellion' in the area Cribb (2000:92).

6 See also Kumar (1979) in Hefner (1990:8) 'After winning control of the region in 1743, the Dutch made up for the shortage of population by encouraging migration from the impoverished island of Madura (Kumar 1979)'. 


\section{Populating the Uplands: Madurese Migrants Coming to Krajan}

Now, two hundred years later, the contrast with the emptiness of the past is striking. Not a single patch of land in the area is unused. Population pressure is high and all land, even the poor pieces, are cultivated or occupied. Over $40 \%$ of the population does not own any land, and livelihood opportunities outside agriculture are few. The population in the rural areas near Besuki, Bondowoso, Situbondo and Jember is predominantly Madurese, and most people in the cities also belong to this ethnic group or are of mixed descent (Retsikas 2007:188).

The early Madurese immigration into the hinterlands of Besuki, Panarukan and Bondowoso created a basis for these later waves of upland settlements. Initially, migrants moved to the lowland areas in East Java where sawah could be established (Palte 1989:18). However, early in the 18th century they were settling in the mountainous areas north and northeast of Besuki. It was this wave of migrants that populated the lower areas of Wringin, Pakem and Bondowoso in the second half of the 18th century. Although Madurese is the mother tongue of all villagers today, it is not certain that the first inhabitants of the upslope regions were all of Madurese descent. ${ }^{7}$

Boomgaard draws attention to the fact that the widespread cultivation of maize in this period, especially in the Eastern Salient, enabled the uplands and semi-permanent dry agricultural land to be populated (Boomgaard 1999:64) ${ }^{8}$ According to Hefner, it was the introduction of compulsory cultivation, especially of coffee, on upland 'wastelands', which led to migration to the uplands

7 There were probably some of the original people still living; remnants of Hindu populations who had fled from wars and the hegemony of new kingdoms or Muslim rule, or people who had fled from the coastal areas. It is possible that in the Argopuro area a similar development took place as in Tengger where Hindus had fled to mountainous areas and survived. Here, the original populations have merged with the Madurese migrants. Boomgaard (1999: 65) comments: 'It is possible that the introduction of maize enabled similar migratory movements elsewhere to successfully establish themselves as "mountaineers," thus constituting "heathen" upland "tribes" (masyarakat terasing in modern Indonesian parlance), who preferred to live at a distance from coastal Muslim-Malay sultanates, the European and Chinese trading settlements, and the risk of epidemics. This, by the way, was much to the regret of the Dutch colonial administration who always attempted to get the mountain-dwellers to come and live in the coastal areas, and to make them grow "wet rice". See also Hefner (1990:9-10) who describes the flight of Hindu Javanese to Bali and the Tengger mountains in East Java (The Tengger volcano and its Hindu population are about 50 kilometres from Mount Argopuro).

8 The availability of a new food crop, maize - which grows well to altitudes over 1,500 metres enabled settlers to continue to spread higher up the mountains. 
in the nearby Tengger area: 'From 1830 to 1850 , therefore, all territory between 600 and 1,200 meters above sea level was stripped of its jungle and transformed into one vast coffee stand. At first, the cultivated expanse was punctuated by only occasional native settlements. Soon, however, land-hungry migrants poured into the highlands' (Hefner 1990:10). Both these perspectives, the food availability thesis and the commercialisation thesis, could be correct. In the area around Krajan, both developments took place simultaneously on the lower and middle range slopes of Mount Argopuro.

Tennekes (1963) shows that the lower Krajan area was certainly populated between 1800 and 1845 , if not earlier. A map of the Dutch Indies (Melvill van Carnbée and Versteeg $1853^{-1862}$ ) notes Krajan as an independent desa in $1856^{9}$ and also shows extensive coffee plantations.

Due to the limited possibilities for further settling, the relatively poor soil fertility and better opportunities on the Bondowoso and Jember plains, the focus of migrants coming from Madura shifted from Besuki and Panarukan to the more distant fertile areas of Bondowoso, Jember, Banyuwnagi and Lumajang. Moreover, the establishment of coffee, tea, rubber and kina plantations, and later tobacco production, attracted new waves of migrants to these areas from the end of the 19th century onwards. The age of plantations thus constituted a second wave of Madurese migrants to mainland East Java, most notably to the plantation districts of Jember, Banyuwangi, Lumajang and Bondowoso.

Another explanation for the early population of higher areas such as Krajan is the desire of villagers to escape the pressures of local rulers, Islamic sultanates and colonial rule which became especially severe after the introduction of the cultuurstelsel in 1830 (Boomgaard 1999, Hefner 1990). Villagers wanting to escape from the pressures of the cultuurstelsel and corvée services (heerendiensten) in the lower areas could settle in the Krajan area, clear forest and 'live undisturbed by the colonial government on their semi-permanent swiddens' (Boomgaard 1999:65). Scott calls these processes nonstate options, state evasion and state prevention (Scott 2009:179, 328). Similarly, Li (1999:26) notes 'fleeing debts and excessive corvée demands, people frequently moved off in search of less oppressive conditions with another master, or autonomy (often temporary) on a forest frontier'. Soon, however, the obligation to plant coffee on their lands thwarted their urge for freedom. The Krajan frontier offered labour opportunities, shelter and relative freedom for those who fled from the pressures of the cultuurstelsel, and statute labour in the Besuki area where the enforced sugar cane cultivation increased population pressures.

9 This atlas, including the maps of East Java, was published in 1856 . 
Prior to 1932, free access to the uphill forest of Krajan was still possible, despite the 1870 Agrarian Law and later regulations that restricted customary rights on waste and forest land. Until the 1930s, in upland Java, villagers continued to clear forests and construct terraces for farming and so slowly encroached into the upland areas (Hefner 1990:51). Oral histories in Krajan confirm opportunities to clear land for fields far into the twentieth century. ${ }^{10}$ In the 1930 , these practices came to an abrupt end due to stronger colonial water-control programmes to fight erosion, flooding and droughts that inhibited shifting cultivation at these altitudes and the further expansion into the mountains.

The population in Krajan continued to grow from this period onwards, and the pressure on the land increased. It was no longer possible to extend the total areal of land and newcomers and villagers who had no access to land had to look for some other livelihood. Land was divided among children, production became intensified, sawah were constructed and some families lost their land to richer villagers. Since the 1930s, the trend of diversification in land ownership has reversed, slowly leading to large inequalities in land ownership.

By the 1960s, agriculture in Indonesia was in crisis. Agricultural production had stagnated, no more peasants could be absorbed and tensions increased. Communists proclaiming land reform gained increasing influence vis-à-vis religious and landed elites. Starvation was becoming a natural event in rural areas and Krajan villagers recalled stories of hardship.

The final years of Sukarno were marked by hyperinflation, infrastructural decline, falling rice production and the flight of foreign capital. Not much is known of the Madurese in Krajan during this period except that the population continued to grow while migration opportunities to urban areas were limited. Geertz (1963) has been among the most influential writers about this period. He sketched an image of rural Java as stuffed with labour and under pressure due to continuous population growth. The sawah ecosystem was able to absorb large numbers of workers through intensification made possible by a shared poverty ethic. Although total production rose, the production per head of population decreased. This could therefore not be accurately called evolution (or development), and Geertz coined the term involution.

His book has been tremendously influential in rural development thinking in East and southeast Asia and served as a basis for persisting ideas on village social security and harmony (see Hüsken and Koning 2006:18-21) that are still influential today. According to Geertz, it was not a class of landlords opposed to rural proletariats (landless serfs) that was formed as a result of population

10 Villagers in that area told me stories of their parents and grandparents about clearing their fields to start farming. 
pressure and commercialisation but a rural society which remained relatively egalitarian; and he argues that 'native institutions maintained a comparatively high degree of social and economic homogeneity by dividing the economic pie into a steadily increasing number of minute pieces'.

\section{From In-Migration to Out-Migration}

The conviction arose in Krajan that nothing would improve by staying in the village and, from this time onwards, the first villagers set out in search of land or work. First to the nearby plantation areas, but soon to the newly opened agricultural areas in West Kalimantan. Very few of these migrants ever returned, and villagers today hardly remember names and families as poor connections and infrastructure at the time made communication almost impossible. In many parts of Java, the hardship of village life proved a fertile ground for communism and the call for land reform became louder and louder. The PKI, the communist party, had its base in the rural areas, with East Java as a stronghold. In the early 1960 s, they tried to outflank their urban rivals by mobilising the countryside and pushing an agenda of land reform.

The years 1965 and 1966 mark the government inspired campaign against the PKI. As far back as the guerrilla war against the Dutch, several Krajan villagers had been sympathetic to communism. Most of them were either secular small farmers or landless occupants from Pakuarah, the upslope hamlets of Pakualas and Wringinkurung and in the neighbouring upslope areas of Andungsari. These PKI supporters were the obvious targets for vengeance from the military and the strongly anti-communist religious groups from outside the village. In the region around Krajan, some were killed, many were arrested, others abducted never to return and most were ostracized and marginalized. As communism is still a delicate subject today, villagers were reluctant to talk about this part of the history of East Java. However, older people from Bondowoso showed me some of the places where bodies were dumped. ${ }^{11}$ The exact numbers of those killed in Indonesia are not known, but some estimates mention one million people, most of whom were living in East Java (Cribb 1990, Ricklefs 1991).

11 One of the places where, according to eyewitnesses, thousands of bodies were disposed is Arak Arak on the road between Besuki and Bondowoso. Arak Arak is a steep rock just below the road, and bodies could be thrown over without being seen from anywhere else due to the dense teak forest below. Other spots where bodies have been dumped are limestone caves around Bondowoso, deep wells and a river canyon in the dense forest between Situbondo and Banyuwangi in the Asembagus area. According to eyewitnesses, bodies were dumped from military trucks. 
In Krajan, only a few people were killed in this period (1965-1966), and in neighbouring Andungsari only ten. The situation was worse in other villages in lower areas of Bondowoso. The relatively small number of people killed in Krajan was because, while many had communist sympathies, only a few had become active party members. This reflects the general tendency in the area to stay aloof from strong involvement in supra-village affairs. As someone expressed it: 'we have always wanted to stay away from lowland influence and government control as it has never brought us any good'. When the killings in the Bondowoso area started, mostly carried out by the military and by semimilitary bands of followers linked to regionally important religious leaders (kiai), Krajan stayed on the sidelines. Krajan's village head (from the nationalist party $\mathrm{PNI}$ ) forbade villagers to join in the killings, and tried to keep his people away from them.

When groups of religious youths from Wringin, Besuki and Situbondo tried to enter Krajan, they were confronted by Krajan villagers and called back by their kiai. The Krajan village head had direct negotiations with him. He had drawn attention to the fact that most Krajanese were true followers of this kiai, and warned that the Krajan population would not support or tolerate any attempt to kill fellow villagers. Although relatively successful in preventing mass killings, the village head had to eventually pay the price for his opposition when religious leaders gained control over local and regional politics and accused him of having communist sympathies. Eventually, the changing political climate after 1966, and his resistance to the new government, forced the village head to step down.

The stage was set for a new government: The New Order. Besides opening up the economy for foreign investment and introducing measures to bring inflation under control, it also launched new initiatives in agriculture, including programmes for the distribution of fertilizers, pesticides and newly developed modern rice varieties. The programmes expanded after 1973 when international oil prices rose and government revenues swelled. After initial problems, the modernisation process became seen as a success. By the late 1970s, the majority of rice fields in Java were planted with new rice varieties and fertilizer use had become among the highest per hectare in Asia. Yields increased dramatically with annual increases of $3-5 \%$. Indonesia's rice production almost doubled in the 1970s, outstripping population growth.

Many of these developments initially passed Krajan by due to its remote location and small number of rice fields. However, from the 1970s onwards, under the relative stability of the authoritarian New Order regime, the village economy of Krajan did open up: more villagers got jobs inside and outside the local economy, trade increased and irrigation canals were improved and 
extended. ${ }^{12}$ Tobacco became a successful and popular cash crop due to the demands of the kretek industry. From this time onwards, village life started to change rapidly and it became possible to obtain the cash necessary for migration. With huge profits from tobacco, land-rich villagers could build brick houses, two new mosques were built, more villagers were able to send their children to secondary school in Bondowoso, some large farmers bought motorcycles - although these could only be used in the dry season on the village's mud roads - and, in the New Order years, twenty to thirty villagers were able to travel to Mecca to make the pilgrimage and achieve the prestigious status of a Haji.

Over the years, with the Krajan population rising, as in most rural populations in Java, the pressure on land increased although very few figures are available for this period. In Java as a whole, average land holdings fell from 0.7 to 0.66 hectares between 1963 and 1973, a process which resulted in $40 \%$ of the rural population becoming excluded from land (Hüsken 1988). Between 1924 and 1976 , the proportion of 'very poor' in Java grew from $3.4 \%$ to $39.8 \% .{ }^{13}$ Inequality in income distribution dramatically increased over these years. At the same time, the absolute consumption of the lowest $40 \%$ did not increase: some informants in Krajan commented that they ate rice with dried fish in the colonial time and, now, they still eat rice and fish. Nothing had changed in their standard of living despite all the development promises by the government. This quote from a newlywed man summarizes the feeling of many youngsters about the possibilities of making a living in Krajan: 'If we want change, we have to move out of here'.

\section{Land and Land Use in Krajan}

Numerous researchers from different disciplinary backgrounds have studied agricultural systems on Java. Some from an economic or historical point of view, ${ }^{14}$ others are more sociological. ${ }^{15}$ In general, these studies have focussed upon the lowlands. Studies of upland agriculture on Java are relatively rare with a few

12 This was desperately needed because deforestation and the poor maintenance of irrigation canals had led to the water supply to far fields diminishing enormously. Nevertheless, the various improvements to irrigation canals during the 1970s, 1980s and 1990s could not prevent some fields becoming dry and being degraded from sawah to tegal.

13 Incomes in equivalent kilograms of rice per head of the population (poverty line $240 \mathrm{~kg}$ ).

14 Boomgaard 1988; Bottema 1995; Van de Koppel and Van Hall 1946-195o; Van der Kolff 1937; Van Schaik 1986.

15 Cederroth 1995; Hartveld 1996; Kanó 1980; Saptari 1995. 
notable exceptions such as Hefner (1990) who worked in the nearby Tengger region, Murray-Li et al. (1999) in upland Indonesia, Palte (1989) who wrote about mountainous Central Java, and Wolters (1998) who has been involved in a longterm study of a Central Javanese mountain village. Leunissen (1982) and (Smith 2011), who did research on Madura, produced the only available studies that describe the peculiarities of Madurese dry land agriculture in detail. As my research concerns an East Javanese upland area populated by Madurese, I will at times refer to Hefner's and Palte's analyses and, when relevant, to Leunissen and Smith to consider the peculiarities of Madurese agriculture.

The agricultural system of Krajan does not fit well into any of the systems described in these studies of agriculture on Java and Madura. The agricultural system of Krajan has concurrently the specific characteristics of Madurese agriculture, and a distinctive highlandness that make agricultural systems in uplands so special. As on Madura, it has a long dry season, is poorly irrigated, and mainly oriented towards cattle, maize and subsistence production; with tobacco as the only cash crop offering erratic returns. The altitude and rugged terrain makes the area remote and hard to access, ecologically sensitive to soil erosion and depletion, and it gives its people a sense of stubbornness, independence and distinctiveness, which can be observed in many mountain communities. Its economy is neither purely based on cash crop production of specific upland crops, nor purely commercialized and market-oriented.

Land in Krajan is divided into sawah, tegal, plantation land, government land (tanah pemerintah/bengkok) and wasteland (tanah liar). ${ }^{16}$ Around $75 \%$ of all arable land is tegal, $20 \%$ belongs to an experimental coffee plantation, while sawah only makes up a meagre $2 \%$ to $5 \%$. The coffee plantation is situated in the upper part of Krajan and it extends into the mountain forest of the upper slope of the Argopuro.

Krajan village data on land are unreliable and still based on land survey reports made in the 1930s by colonial surveyors. These surveyors made a distinction

16 The categories of government land and wasteland are locally contested. In general, wastelands are mountainous areas and steep slopes unsuitable for any type of agriculture (except for cutting fodder). According to Bagenda, the village head, wasteland includes land along brooks, roads and rivers, and for this reason belongs to the village officials and especially to him: ignoring all kinds of customary rights and grazing rights of villagers in these areas. During the period 1992-1998, he ordered, several times, trees to be planted in these areas, giving him (according to local law) ownership rights over these trees and the land. Most of the trees planted however 'died'. Farmers can think of numerous accidents leading to trees not surviving. Other wastelands are the forests higher up the mountains. Here village borders are unclear and these wastelands are government land controlled by the Department of Forestry. 
between first, second, and third class sawah: based on the productivity of the sawah and the reliability of water. On first class sawah, rice can be produced the whole year round, while third class sawah is only irrigated by small brooks in the dry season and may yield only one crop of rice a year. Today, second and third class sawah are no longer used to produce rice due to a lack of irrigation water. According to official village statistics, Krajan has around 50 hectares of first-class sawah, $4 \%$ of the total village acreage of arable land, 25 hectares of second-class sawah, and about the same of third-class sawah. Based on my own observations, today, only about 50 hectares of sawah remain, most of which is of low quality (these fields are split up in hundreds of small pieces and terraces belonging to different families). Comparing the amount of sawah in 1922 with the amount in 1999, the total acreage of sawah has decreased with more than $50 \%$. Due to major deforestation and erosion from the 1930s until the 196os in upslope areas; small brooks, wells, and old irrigation canals have become dry thus turning formerly first class sawah into second or third class, or even into tegal. New Order irrigation projects tried to reverse this trend and made it possible to irrigate some new areas, mostly owned by village officials. Recently, many of these irrigation canals have decayed again.

Even the best sawah remaining are of a much lower quality than those that are generally found in the Javanese lowlands. Rice yields in Krajan are lower due to the less favourable conditions related to infertile soils, a cooler climate, and less available inputs. In Krajan, good sawah can be planted two times a year with rice. As for most sawah water supply in the dry season is unreliable, one or two crops of maize are often planted after a first crop of rice. Most low quality sawah lie fallow in the dry season, and are only planted with rice when the rainy season is well established and when the rains are most reliable. On these sawah, a crop of maize or tobacco follows the first crop of rice. In general, the quality, taste and price of tobacco produced on sawah are lower than on tegal, although production is higher.

Farmers themselves make more distinctions in soil quality than simply first, second or third class. Soils can be 'cold' or 'hot', 'heavy' or 'light', 'shallow' or 'deep' and 'thirsty' or 'saturated' indicating different grades of fertility, soil texture, construction, temperature, elevation, location, and water-holding capacity. According to older farmers, it is important to 'know' the soil and its character in detail. In some soils, young seedlings can be planted, while in others, seedlings have to be taller. A sawah can be 'sensitive', prone to diseases or 'nakal' hard to understand/hard to master, sometimes giving good yields but low yields in other years. In some sawah, 'the water source is coming from below' indicating that water wells up in the field and therefore contains fewer nutrients while other sawah can be 'polluted' if the water sources run through 
a hamlet picking up dirt and nutrients. Understanding these minor, often invisible, qualities is essential for successful tillage. Fertilizing 'warm' or 'polluted' sawah leads to weak rice and empty grains as the soil receives too many nutrients, whereas under-fertilizing a 'cold' field or sawah with a hidden water source or leads to smaller plants and poor yields. The repertoires of local knowledge are important for success in farming on these varying soils. ${ }^{17}$ These are based on personal experience, common knowledge and information from older people, and acquired from small-scale experimentation by farmers. Owning, or having access to, the right repertoire of knowledge, is essential for a good harvest. When persons migrate, this knowledge is lost.

Ownership of good sawah in Krajan, as elsewhere in rural Java, is highly valued as it has economic, cultural and social functions. It not only offers food and income security, as good sawah enables its owner to cultivate food crops the whole year round, it also adds status. The ability to grow one's own rice on one's own fields is very important and someone's status is measured primarily according to the number of rice fields they own.

In the past, less than half of the families who own sawah have ever been selfsufficient in rice. ${ }^{18}$ Nowadays, only $10 \%$ of the families are fully self-supportive in rice. Krajan inhabitants own most of the sawah in Krajan. Sometimes villagers marry and move to a neighbouring village and maintain their sawah in Krajan. Krajan villagers have also bought rice fields in neighbouring Ardisaeng and Andung. Although distances are far to those villages and fields, according to these landowners, it is better to buy sawah in another village than not to have any sawah at all.

The arable lands of Krajan also comprise 800 hectares of tegal. Some pieces are rather large, while others are tiny and carved out on steep slopes. Farmers distinguish dry lands of good, middle and bad quality. These qualifications of good and bad are not always fixed, but depend on the location and the crops farmers want to plant. Tegal is used for growing subsistence as well as cash crops. Although the fertility of Krajan tegal is not very high, sometimes with tobacco huge profits can be made. Depending on the crop, the tegal soils need various labour inputs.

Before the rains start in October or November, the tegal is worked with a simple plough and two oxen. As soon as possible after the first rains - when the

17 See for studies on local farmer's knowledge: Chambers, Pacey and Trupp 1990; Geertz 1983; Richards 1985; Scoones and Thompson 1994; Van der Ploeg 1990; Van der Ploeg 1999; Van der Ploeg 2010.

18 This figure is probably too rosy, as in the past all families mixed their rice with cassava, sweet potato, or maize. 
soil is wet enough ${ }^{19}$ - the field is ploughed again while maize seeds are thrown into the furrow. Early planting is needed, as the growing period for maize is long (four months or more in upslope Krajan) and the rainy season is short. After the first maize crop, on fertile fields a second maize crop can be planted. On the less fertile fields, tobacco is planted. Tobacco is best planted on shallow, sandy and poor tegal soils as this produces a much better flavour and yields a higher price. It depends on the soil quality, the price of tobacco, maize, fertiliser and the strategic choice of the owner, which crop is planted. A good tobacco harvest provides the opportunity to buy enough maize and rice to survive the long dry period. However, growing tobacco is expensive and bears the risk of total crop failure and thus losses and indebtedness. A second crop of maize will at least offer some additional food, and limit expenses as local maize varieties do not require any inputs. Thus, the agricultural landscape of Krajan serves as the enabling context in which people make livelihood choices.

The ownership of tegal is symbolically less important than that of sawah. If someone is called rich, villagers usually mention only the possessions of sawah. If someone has a lot of sawah, then he or she will generally have a lot of tegal as well because most Krajan farmers prefer a combination of sawah and tegal. Tegal offers the opportunity to grow maize and tobacco in addition to the important rice crop. It can also be pawned in the event of an urgent need of cash, and it changes hands somewhat more readily than sawah.

A frequent leasing or long term pawning of tegal leads to decreasing soil fertility. Pawned tegal is less well cared for than privately-owned land. Soil fertility in the long run can only be guaranteed by applying cow dung or mulch and compost. The availability of dung is limited and carrying dung too far away fields is laborious. Landowners choose to dress their own land first, before caring for their leased land. Often they do not bother about the long-term sustainability of the leased fields because of the fact that they can always be taken back. These differences between leased and owned lands are often visible in the way they are intensively or extensively cultivated.

Another crucial factor in the sustainability of tegal soils lies in the differences among sharecropping systems. If landowners give land out to subcontractors, soil quality is likely to fall. In Krajan, sharecropping maize production is rare, but with tobacco production it is common practise. With maize,

19 Farmers use the length of a hand as an indicator of whether the soil is wet enough. They dig small holes at several places in the field and measure to what extent the rain has entered the soil. If the soil is wet for a hand's length, maize can be planted. As rainfall is sometimes very irregular and localised in Krajan, some fields are planted weeks later than others. 
important labour arrangements exist, including working in turns (labour exchange groups and harvest shares), part of a share tenancy relationship where the workers get a one-fifth share of the harvest. Usually, in these arrangements, workers are more concerned with the quality of the work and maintaining soil fertility as they receive a harvest share, not a cash income.

If only a little manure is available, people use it for their home gardens (pekarangan). Most houses have at least some gardens with fruit trees and sometimes vegetables. In these gardens, jackfruit, bananas, papaya, coconut, coffee, chillies, cassava and taro are among the most common crops. Pekarangan in Krajan are not big and they only contain a few fruit trees. In general, these gardens do not contribute much to household incomes, but in the event of temporary shortages, villagers can fall back on fruits and vegetables produced on them. Moreover, the fruits and vegetables of the home gardens form a significant supplement to the daily diet (Singarimbun and Penny 1973).

The forest above the village is an important resource, especially for poor villagers. Access to the forest is relatively open as with other wastelands, such as roadsides and riverbanks. The forest is used for searching for fodder, firewood, lumber, and small bamboo sticks suitable for making baskets. Poor villagers can earn $€_{1-2^{20}}$ a day by carrying firewood or bamboo down from the forest and selling it in hamlets and desa lower along the road. One return trip to the forest takes around six to seven hours and, especially in the rainy season, carrying wood is hard work, but up to $€ 4$ per day can be made.

Although the government officially owns the forest, and prohibits logging, many villagers cut trees in the forest and sell lumber. At the beginning of the crisis, around 25 people were regularly cutting wood and selling this to fellow villagers or to the village head. The latter was able to sell this wood 'legally' with the help of police friends and government employees in town. He explained it as help: "I help my "children" [the villagers] to make some profit and make a living.' Clearly, he does not solely intend to help the poor villagers as he has made huge profits on the wood for himself. He did, at least, provide loans to selected villagers if they needed money. These loans could be repaid in wood, and to those working for him he offered protection through his good relationship with the forest police.

As cutting and selling illegally logged wood is very risky, relatively large bribes have to be paid to local officers of the forest department and sometimes also to the police. Around the 1999 national elections, he stopped accepting wood as loan repayments and villagers were forced to find ways of selling the

20 I use Euro's here, as the wages have been changing from Rp 3,000 in 1997 to Rp 15,000 in later years as a result of inflation. 
wood themselves. He decided to free his hands so that he could lead the election campaign of the PDI-P, and refused further help to villagers who had problems with the forest police. From that time onwards, only a few villagers had the courage, or network, to continue their forest business. Around $10 \%$ of the population uses forest products from time to time, and for $5 \%$ of them access to the forest provides their main resource.

To be successful as a logger, at least some relationships with the forest officials are needed. In a small and hilly community such as Krajan, illegal loggers and their products are easy to trace. Lower ranked forest officials who live in Krajan can be offered 'money for petrol or cigarettes', petty bribes. Powerful high officials are more difficult to bribe for ordinary villagers and meeting such an official in the forest can easily become a disaster and lead to imprisonment. Therefore, villagers need protection, and the village head can offer that as he has always maintained good relationships with police and forest officials.

Recently, some farmers and village officials have started with planting trees on the least fertile plots, or upland plots far from the village centre. Besides teak, which always has been planted at wastelands and at borders of plots, new varieties planted are sengon and meranti. ${ }^{21}$ The afforestation might be a sign of structural changes taking place the village: a decline in population pressure on the land and a further exclusion of landless labour out of the village economy. Trees are only be planted by people who own land and on these lands no longer need wage labourers to grow maize and cassava.

\section{Land Transactions}

Villagers who have been successful in trade, politics or business eagerly try to buy sawah for reasons of prestige, security, and collateral, even if they could have invested their money more efficiently elsewhere. Sawah is rarely sold and villagers only do so if they have no other choice. Most land transactions happen through pawning of fields. As the price of tegal is much lower than sawah (good tegal costs about one third of good sawah) more people have the possibility to buy or lease a piece of tegal. Tegal is also sold easier to cover costs when people face bankruptcy, gambling debts, urgent needs of money, and sometimes demands from children who beg their parents for a transport van, stock for starting a shop, or a motorcycle.

In 1997, two villagers sold land to buy a pick-up truck to transport goods and villagers to and from town. They were quite successful. In 1998, another family followed their example and sold land as well. During these years, competition on the road between transporters, both from Krajan and outside, increased

\footnotetext{
21 Meranti (Shorea Spp.), sengon (Albizia falcata), teak (jati) (Tectona grandis).
} 
and some of the drivers went bankrupt. In particular, the last family who had sold land faced severe difficulties finally sold the car. Other villagers commented: 'Now you see. Never sell land'.

Sometimes, large plots of land are sold to buy a motorbike for a demanding child. Parents cannot always refuse the demands of children to sell land, even if this would make them the subject of gossip. All villagers agree: selling land on the demand of children, for consumption goods, or even for repairing a house is not good. In practice however, sometimes even sawah is sold to meet these demands. A decade ago, a number of villagers (mostly from Wringinkurung) sold sawah to pay the high school education costs of their children. When most of these children failed to secure a good job - and could not repay the investment - other villagers said they would not follow this example. Few children from Krajan finish high school and only one finished university. Selling land for the education of children is regarded as consumption rather than as an investment and is perceived as not wise.

In contrast to selling land, pawning (gadai) is a common practice and a major mechanism for accumulation and dispossession. Villagers in need of cash, pawn land in return for money, cattle, gold or sometimes sugar. The most common way to pawn land is to ask for one or more cows or bulls that can then be sold at the market. This is a public way to transfer the use rights of land as all villagers can witness the transaction: the cows or bulls will be transferred in daylight and exhibited at the house of the pawn giver, and after the transfer at the house of the pawn taker.

When families are confronted with unexpected expenses, as for instance in the case of death or hospitalisation of a family member, pawning land is a fast way to obtain money to cover the costs. The Satrawi family pawned land on several occasions to Patik. When their daughter was in hospital and the doctor's fees had to be paid, Satrawi asked Patik (their patron and neighbour) for a bull of about one year old in return for a piece of sawah. On the first available market day, he took the bull to Bondowoso with Patik who advised and assisted in selling the bull for a good price. After the transaction, Satrawi went directly to the hospital to pay the fees. By pawning his land, he still kept the option of reclaiming it whenever there would be a windfall or an improvement in his financial means. Although Satrawi had intended to pay back an animal as soon as possible, he later had to pawn more land. Now the family has fallen into poverty, even their children might never be able to pay back animals and so return the land to the family. In some cases in Krajan, children were able to get the land of their parents back after more than thirty years.

In general, a gadai loan can be repaid in parts, animal by animal, or it can be increased if more cash is needed. This will naturally only happen if the creditor 
has money or an animal available, and is willing to increase the loan. Often he or she will try to refuse, as he or she already has the use-right and does not earn additional benefits by adding to the price. If the loan is not increased, other people can take over the gadai by repaying the loan and by giving additional credit to the owner. This is not very popular as it reflects a severe breach in the relationship between parties but nevertheless, during my stay in Krajan, I witnessed several cases. Satrawi once tried to go to pawn his land for a higher price to pak Heri. Heri was willing to provide two cows for the field pawned previously to Patik for one bull. Patik fiercely objected, as a cow was not similar to the bull he had provided, and he did not accept cash as repayment. Finally, the deal with Heri was cancelled. He was not willing to risk his good relationship with the Patik family and their relatives and friends.

If the credit supplier does not want to increase the loan, and the owning party still needs or wants more money, the land can be sold to the creditor. If the creditor cannot, or does not want to buy it, someone else can buy. When selling land, the transaction has to be registered at the village office and at the land administrative office at district level. For powerful people, land transactions with the government, or government related institutions, can be quite profitable. In the last decade, Bagenda has been involved in several of such transactions making nice profits. In the 196os, the village head (grandfather of Bagenda) asked the government to buy village land to establish tanah bengkok and indeed a few patches of sawah were bought. Later, when Bagenda became the village head of Krajan in 1991, he asked the government for more land to be bought. When money was made available to buy sawah, he bought run down, cheap plots of tegal that once had been sawah. These pieces were still registered as first class sawah and Bagenda reported the purchase of first class sawah. He used the surplus money for his own ends. In this way, he both followed the government's request to buy a fixed amount of sawah and made a nice profit. In the village, he led the people believe he received money for tegal, not for sawah. As the lad was bad, he planted trees on them.

\section{Farming for Food: Livestock, Poultry, Crops}

Important sources of income are cattle production, maize and rice. With a population of 3,400 people, over 1,500 head of cattle are raised in Krajan. An adult is able to raise only one or two cows on his own because grass has to be cut every day and brought to the shed where the cows are kept. Most of the people who take care of cattle do not own them. They raise cattle of other people and get half of the profit or offspring. Poor villagers, or newlywed couples without cattle, can borrow a cow or bull from others to make a start, if they are considered as reliable, and capable of raising cattle. Generally, cattle 
owners and caretakers are relatives, neighbours, or friends, and their relationship often has many features of a patron - client bond. ${ }^{22}$

Other livestock such as sheep, goats and horses are relatively unimportant in Krajan. The government has supplied goats a couple of times in its IDTprogrammes ${ }^{23}$ to help 'backward' villages, but these programmes have been rather ineffective as villagers tried to sell their goats as soon as possible, and village officials took their cut of the benefits. According to villagers, the goats were difficult to keep inside, and then destroyed the crops of neighbours, were noisy, and smelled. Many men and women expressed their disgust of goats and the meat is rarely eaten. ${ }^{24}$ Nowadays, widows can be seen every now and then tending goats which they received from a goat programme along the roadside or on harvested fields as goats can eat nearly all crop leftovers. For them, goats can serve as an additional source of income.

Maize is less valued than rice, but it is the crucial staple food-crop in Krajan, guaranteeing most villagers a basic level of subsistence. Madurese are fervent maize eaters. According to Boomgaard (1999: 50) these food habits are very old. Maize is important for food security because it is cheap and it can be stored for long periods and retains a good nutritional value. Maize can be cooked, processed as flour, and eaten as porridge, or baked like pancakes. Young maize cobs are cooked or roasted as a snack.

Local varieties of maize are stored as unpeeled cobs in houses above the fireplace. When needed, the maize is peeled, ground and cooked with rice in the ratio of 1:2. Higher proportions of maize are not appreciated and - according to villagers - difficult to swallow and digest. However, poor people who cannot afford to buy much rice have to mix more maize in with their rice and, accompanied only with vegetables, this results in tasteless and heavy dishes, albeit of good nutritional value.

There are a large number of local maize varieties in Krajan. Farmers distinguish many of these by local names such as jagung Madura, jagung manis or jagung putih. All of the local varieties belong to the 'pearl-seed' type. Short varieties with cobs between 5 and 10 centimetres in length (Leunissen 1982:74). These varieties need little or no inputs, give only small yields, but are very reliable. Local maize varieties have a good taste, can be stored for long periods and can be grown on every soil type. The growing period of these varieties is long (up to four months) and production is purely intended for the subsistence of

\footnotetext{
22 For a description of these caretaking arrangements for cows and bulls see Chapter 3.

23 IDT means Inpress Desa Tertinggal.

24 People often commented: 'We are Madurese, and Madurese people do not like goats, we are only happy with cattle'. Some even refuse to eat cow meat.
} 
the household: it is barely commoditized and seeds are freely exchanged among villagers.

During recent years, new seeds have been introduced by government extension programmes. Hybrid maize varieties need better soils, more fertilizer, more care and work, and the seeds are expensive. They are however, more prone to drought, heavy rains, wind, pests, and bear higher risks as they are more expensive and always need fertiliser. Especially on the higher slopes of the Argopuro, where rains are very unpredictable and heavy winds often occur, the risk of a harvest failure is considerable. Only the somewhat larger farmers decided to try the seeds as they had enough land to takes some risks. They reserved a small part for the new varieties, and planted the rest with old maize varieties.

Basically, there were three types of responses by farmers to these new seeds. The first group carefully applied fertiliser and followed all the instructions on the seed packages aiming at a maximum yield. They spent relatively large amounts on fertilizer and labour. The second group reduced the fertiliser and labour as much as possible and so reduced costs and potential loss in the event of failure. The third group interpreted the instructions of the seed company according to their own needs and circumstances. They selected their best fields with 'warm' soils and applied little fertiliser, but a lot of manure and labour. The first group got the highest yields, while some of the farmers of the second group had the worst yields. Some crops were damaged due to damage by heavy rains and winds. The last group, in general, did not achieve the highest yields, but were the most successful in economic terms. By saving on inputs and investing in locally available techniques and resources, they farmed the most economically and made the best profits. ${ }^{25}$

A smaller proportion of about $20 \%$ offered the workers a cash wage instead, thus radically changing the relationship between landowner and labourer. About half of the landowners did not change anything. Both landowners and those taking harvest shares were forced to sell most of the maize because of its lower quality, or exchange it for local varieties. Suddenly, maize had become a commodity in Krajan.

Rice is the favoured staple food in Krajan, but total rice production in Krajan is nowhere near able to meet village demands. Rice prices are relatively high when compared to other staples. Rice has a high economic and cultural exchange value. Rice can be sold, and it can be exchanged for other goods, for services, or for assistance. Rice can be borrowed, used as a gift (sumbangan), used as collateral, or invested in a mutual exchange, and it is needed for several religious duties (such as zakat, selamatan). Rice is an important commodity in 
Krajan society, and the possession and consumption of rice means a lot to villagers.

In Krajan, two major types of rice varieties are planted, and used mainly for household consumption. The first type includes the old long-stalk and sticky rice varieties. The second type includes the new, high yielding, varieties. These new varieties, introduced since the Green Revolution, have short stalks, a shorter growing season, are more receptive to fertilisers and give higher yields. They are often referred to as 'modern' varieties and were expected to replace 'traditional' varieties completely. The 'new' varieties used in Krajan are now more than thirty years old. Still about one-third of all the rice planted in Krajan is long-stalk varieties. The older varieties are not grown out of tradition, but for economic, ecological, technical and cultural reasons. Growing old varieties attributes more status, they do not require much fertiliser, are risk prone and simply taste better. Also according to some villagers, traditional rice varieties only 'work' in rituals and blessings.

The most commonly planted variety in Krajan at the end of the 199os and early 2000 s is the 'new' IR 64 , which is a quite reliable variety offering high yields, but yielding rice of low taste and low quality. In Krajan, IR 64 has been planted since the end of the 1970s. Although newer and 'better' varieties are available nowadays, IR 64 is still planted because it is, according to farmers, suitable for local conditions. Some farmers experimented with other varieties, but often these tests are not satisfactory. The newer varieties offered less reliable crops susceptible to crop failure and seeds are hard to get.

The old varieties planted have local names like padi Bulu (hairy), padi Bali and padi Kapor. These varieties are planted in sawah of lower quality with less reliable access to irrigation water, in upslope and thus colder areas and by farmers who prefer the reliability, the better taste and the specific cultural arrangements attached to this variety. Nowadays, in general, on sawah in the upslope region (above $800 \mathrm{~m}$ ) old varieties are planted, whereas new varieties dominate on sawah in the mid- and low-slope zones. Farmers often combine both old and new varieties and prefer to plant these varieties simultaneously. It depends on the specific orientation of the farmers in terms of village norms and values, the location and quality of the sawah, family habits and specific household needs, which variety is planted.

During the Green Revolution years (1970s) planting old varieties below 1,000 metres was forbidden. Although most sawah in Krajan actually lies below this altitude, these varieties have always been planted in the lower parts of Krajan and Andungsari. Most villagers managed to circumvent the rigid government regulations related to the Green Revolution and continued planting old varieties on the isolated sawah of Krajan. Nowadays, control on planted varieties is 
less strong, and old varieties can be seen in the lower areas of Ardisaeng and also close to the road. Villagers who do not have local varieties and need some of this rice for rituals or special occasions can barter for them, but not buy them. I never came across any cases of selling and buying of these older varieties. Although organic farming has been pushed by the region government, in Krajan, it did not appeal. Farmers report difficulties in marketing and unreliable prices.

\section{Wealth and Poverty in Krajan}

Krajan is a differentiated rural society, in which villagers have unequal access to land, cattle, employment, and other forms of property or income. This section deals with the ways in which villagers, either directly or indirectly, have access to these resources. Direct access is constituted from command over and ownership of resources; indirect access is mediated by labour arrangements, shared tenancy relationships, social relationships, or inherently by specific modes of production. It considers a number of questions. How are resources distributed in Krajan? How, and by which means, do people gain access to these resources? And who are the most marginalized people of Krajan?

\section{Wealth Ranking and Poverty Categorization}

Socioeconomic inequalities are obvious to all villagers, and in assessing each other's wealth and status in the local hierarchy, people seemed to use a classification and ranking system on which nearly everybody agreed. In its most general form, it roughly follows a tripartite division of the population into three classes: the well off, those who can more or less manage, and the poor. In discussing individual cases, however, people make further subdivisions, and the overall local wealth-ranking system turned out to consist of six categories: 'rich' (kaya), 'enough' (lebih or sometimes called maju), 'just enough' (cukup), 'insufficient' (kurang), 'poor' (miskin), and 'destitute' (susah or kasihan) (see Figure 1). ${ }^{26}$ Interestingly, similar categorisations are found in different areas of the world.

26 Throughout this section, I will use Indonesian terms if available. Sometimes, words are the same in Indonesian and Madurese, although they can have different connotations. Here I mention the equivalents of the words used in the text in Madurese. In Madurese kaya is also kaya (or sogi, more polite), lebih is lebbi, or langkong (polite). Another Indonesian/Madurese word often used for this category is maju. Maju has the connotation of being prosperous, but developing, not yet kaya. However, not everybody in this second class is making progress and, for that reason, I prefer to use the neutral term, lebih. 

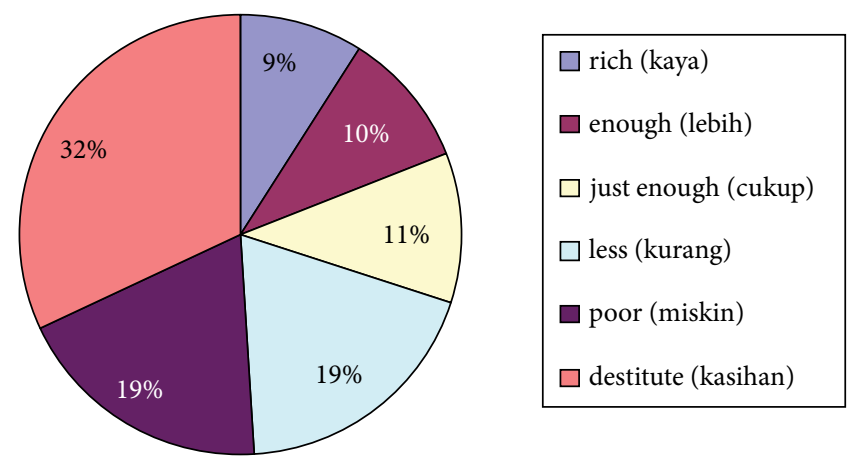

FIGURE 1 Wealth ranking and percentage of total population

Recent research of Ton Dietz and the PADev group shows quite similar categorizations in Ghana, Kenya, and Burkina Faso (Dietz et al. 2013, PADEV 2012).

According to local criteria, one in eleven households is called kaya (rich), while nearly one third are seen as susah or kasihan (destitute). The criteria, with which villagers categorize their neighbours, are rather generally agreed upon. Among the rich we find the larger landowners who produce for the market, some government officials (including the village head and his relatives), and relatives of the former village head, some large tobacco and cattle traders, and some large cattle owners. Among the lebih or maju (enough) we find welloff villagers such as large and middle-sized farmers, businessmen, teachers, and influential people such as hamlet heads and religious leaders. The cukup (just enough) are predominantly middle size and smaller farmers, small traders, and skilled labourers. The kurang (not enough) are small farmers, small cattle owners, petty traders, and wage labourers. Among the miskin (poor) one finds most of the landless and the people without cattle, rich relatives, and regular work. Finally, the susah or kasihan (destitute) are those who live at the margins of village society. They are often old and disabled people, or villagers who are not able to make a living and do not receive care from kin or neighbours on a regular basis. They face regular food shortages, live in small and shabby houses and face poor health.

Cukup is in Madurese cokop, pas, or genna, kurang is korang, miskin is tak cokop, sakoniq, mesken. Susah (sara in Madurese) means difficult and refers to people having difficulties in making ends meet. The word kasihan (niser in Madurese) is more often used in Krajan than susah and has different meanings in different contexts. In general kasihan (niser) refers to people who are pitiful, helpless, lonesome, having bad luck, or in grief. In a context of wealth and poverty, kasihan has a quite strong meaning and indicates that people are to be pitied and live a poor and destitute life. Kasihan in the context of poverty is somewhat stronger than the Madurese word niser meaning down-and-out, or poor thing. 
Naturally, villagers are well aware that these categories are not static, and that people may be downwardly or upwardly mobile - as the cases of Satrawi and Patik cited show. People continually watch each other, as the relative social status of fellow villagers may change and need redefinition. Knowing the economic and social position of friends, neighbours and relatives, constitutes strategic information. It is important to know with whom social relationships should and could be established, to know expectations about consumption levels and gifts at selamatan, and it is important for assessing the creditability of fellow villagers. It is clear that this watching, valuing and discussion of each other's wealth and status takes place in a context of rumours, gossip and jealousy. Having a new sarong, radio, golden necklace, or even a new flashlight can easily lead to rumours or gossip in the neighbourhood.

One day, Hassim, one of my poor neighbours, bought a big new flashlight. Two days earlier, his wife had borrowed some money from one of the neighbours to buy a few kilos of rice. Instantly gossip started, and the neighbour asked Hassim's wife to repay the loan instantly, as she was not inclined to finance their 'unneeded expenses'. She commented: 'Why did you not go to your husband for money. Are you married to me?' Hassim's wife had no cash money to repay the debt, and neither did her husband. The rumours made her ashamed to ask anybody in the neighbourhood for a loan, she eventually decided to sell some of her much needed maize stocks to the shopkeeper.

In the village, there is ongoing borrowing and lending ${ }^{27}$ and information about villagers' credibility is crucial for traders, shopkeepers, village officials and moneylenders. Neighbours, friends, and relatives, are also keen to know every tiny detail of each other's household budgets: to know the amount of support that should be given or received, and the credibility of other villagers in mutual exchange and mutual help relationships.

$B u$ Patik, for instance, is well known for her skills of gathering strategic information to regain debts. She has close contacts with women in the neighbourhood, and many guests and labourers visit Patik's house in

27 See Lont (2002) who describes these complex and multiple borrowing and lending operations for an urban kampong in Yogyakarta. Many villagers have simultaneously debts and loans, and fill one gap or repayment by taking new loans referred to locally as 'gali lobang, tutup lobang'; (lit. digging a hole, filling a hole), robbing Peter to pay Paul. 
search of work, gossip, a free cup of coffee, or some free tobacco. From them, $B u$ Patik obtains all she needs to know about trade, profits and prices. Being the wife of one of the richest villagers, she regularly lends money to workers, relatives, and neighbours in return for assistance and loyalty; in that way she is able to mobilize a pool of workers when she needs them urgently. Most of her loans are very small; the equivalents of a few kilos of maize or rice, but some labourers borrow larger amounts. When $B u$ Patik heard that Pak Sulama, one of their labourers, sold his calf she instantly went to his house to reclaim an old Rp 50,00o debt for last year's Idhul Fitri. When she arrived at the house, Sulama said he had not yet received any money. The next day $B u$ Patik went again, but Sulama's wife said that her husband was away for work, but others reported that he had been at home. On the third day, she went before dawn and waited in front of the house until the family woke up. She did the same the next day, and finally, after five days, she received her money. 'I will not lend to him again', she commented to other guests at her home, thus reducing Sulama's credit worthiness in the neighbourhood.

\section{Households}

Although most transactions take place between individual parties as husbands and wives tend to manage separate funds, exchanges in the village, such as sumbangan, gift giving and support, take place between households. In this book, I therefore take households as the units of analysis, which I define as groups of people who eat from one kitchen or fireplace, not necessary always eating together or at the same time, but as a unit that shares food and resources on a regular basis. Using households as units of analysis does not assume that all resources within the household are pooled, shared or redistributed, nor that livelihood activities, incomes and opinions are uniform or agreed upon. Naturally, households are not homogenous units with regard to resources. A household is often a place of contest, an arena of struggle, full of contradictions between the interests of men, women, children and grandparents.

\section{Social Classes in Krajan}

A clear demarcation line could be drawn in the village between the 'haves', the rich, enough, and just enough, and the 'have-nots', the not enough, poor, and the destitute. The first grouping are those who have adequate land, are financially independent, and can buy more than basic needs only, while the 'havenots' face chronic or periodical difficulties in making a living. A general point for calibration between higher and lower classes in terms of wealth ranking is 
the notion of cukup. According to Krajan villagers, cukup means being able to provide basic household needs, which means that the family can eat enough (two or three meals a day); eat reasonably well (with vegetables, soy cake, or dried fish); buy clothes for the whole family at least once a year; smoke cigarettes or tobacco; chew betel; regularly buy (once a week) tea or coffee; contribute appropriate sumbangan and small gifts to others at weddings, funerals, and lifecycle rituals; and produce a significant number of cookies and simple meals at selamatan and at Idhul-Fitri at the end of the Ramadan. In short, cukup implies to have enough to fulfil household needs and to be able to live decently, being able to perform all the required selamatan and other social obligations in the village. At least half of the households are not able to do this on a regular basis, and another $19 \%$ faces periodical difficulties in doing this.

\section{The Rich (Kaya)}

In Krajan, only a dozen extended families are seen as rich. Some of them have become rich in land and cattle, others derive their wealth from business (mainly tobacco trade and cultivation), from inheritance, or from their political position. Three of the richest families of Krajan have provided all the village heads since history, and most of these richest families have members who are involved in village politics or active as village officials such as kepala dusun, water officer, village secretary, member of the village development board (LKMD), or head of religious affairs.

Among these rich, the two leading families compete and dominate village politics, each representing one of the two factions in the society: the secular and the religious. The secular (abangan) family of the village head Bagenda and his mother, $\mathrm{Bu} \mathrm{Ti}$, is currently on the rise. Bagenda owns a few hectares of sawah and tegal, a brick house, a car, a pickup truck, a new Honda motorbike, a large dish antenna and television set, and all sorts of conspicuous consumption goods such as a refrigerator, cameras, and mobile phones. He derives his wealth from privileges and levies that come with his position as village head, from government projects, from a variety of (legal and illegal) trades, and from his sawah and livestock. Moreover, his mother, $B u \mathrm{Ti}$, who owns another few hectares of sawah, tegal, and over 20 head of cattle, supplements his income and finances most of the trades. In addition, $B u$ Ti deals with most of the money lending and retailing from her thriving shop in the village centre. ${ }^{28}$

28 Villagers say she owns over fifty head of cattle, but I could not trace much more than a twenty. Bagenda likes to boast about his richness to impress villagers, but in many cases, his wealth was not as great as he boasted. In practice, much of his wealth is derived from profits he made from government projects, and loans from credit schemes rather than 
The dominant family from the religious circle in Krajan is the Haji Feisal family living in Mengkuara. The father of Haji Feisal was village head from the end of the 196os until 1992. In that period, the family prospered and acquired much of its current wealth. Moreover, since they came to power in Krajan, seven family members have been to Mecca to become a Haji. They own a few hectares of second-class sawah, and over fifteen hectares of tegal on which they grow predominantly cash crops such as tobacco, onions, groundnuts, and improved maize. Besides this, they have at least fifty head of cattle, which are tended by poorer families in the neighbourhood. Their compound consists of three brick houses with marble floors, a private praying house to teach Koran to the children from the neighbourhood, and a shop. Moreover, they own a truck for trade and transport, a luxury car, and several motorbikes. They maintain good trading relations in the tobacco area towards Maesan and Jember, and with the most important religious leaders (kiai) in that region. During peak times in the tobacco season, they employ over $100 \mathrm{men}$, women and children. Unlike the Bagenda family, they do not contribute much to selamatan, weddings and funerals of the people who work for them, and they rarely loan money. Since Bagenda became village head in 1992, business and political competition between these two families is fierce. From around 1998, it seems that the Bagenda family is doing better, ${ }^{29}$ while the Feisal family is losing some of its hegemonic position in the lower Krajan zone. The Faisal family made heavy losses during the droughts of 1996 and 1997, due to low tobacco prices in 1997 and 1998, and are relatively hard hit by the need to pay higher wages to the labourers these days.

The other rich families of Krajan mostly live in Dluwang, Wringinkurung, and Pakualas, and derive their wealth mostly from local resources such as good quality sawah and tegal, and large numbers of cattle. Some of these families belong to the religious, others to the secular, camp and invest in land and cattle, fighting bulls, prestigious selamatan, or cattle trade. They control large numbers of poorer families in the neighbourhood who work on their lands for a share of the harvest and who look after their cattle. Although one or two of them have built brick houses, most of these families live in traditional wooden, decorated, houses, do not own motorcycles or television sets, and try to stay slightly aloof from the cash economy. One of the newly rich families has a child in Malaysia who regularly sends money. She is said to be working as a domestic

from earnings out of farming or business activities. Much of his business has collapsed soon after being started.

29 Success continues. After 2000, Bagenda became member and later chair of komisi III dprd in Bondowoso for several terms. 
worker, but some others say she is a sex worker. 'How would she be able to send so much money home?'

\section{The Enough (Lebih or Maju)}

The enough villagers are well off. Among them are some nouveaux riches like such as businessmen, teachers, and some returned migrants; ${ }^{30}$ influential people including hamlet heads, and religious leaders; and also families who once belonged to the village elite, but have now somewhat fallen back. The new rich usually own brick houses with ceramic-tiled floors, while the older and former elite often live in wooden, decorated, houses with cement floors. The enough generally own enough sawah to be self-sufficient in rice, but they own considerably less sawah and cattle than the rich. Many of the enough own large plots of tegal. Many of them are involved in tobacco cultivation, large-scale trade, and borrow or lend large amounts of money. Due to sharp fluctuations in prices and quality of tobacco over the years, their wealth is not always steady and their money comes and goes easily.

Other people ranked among the enough are skilled craftsmen, such as constructors, and educated people who have become members of the village administrative system. Teachers and health workers are generally ranked among the enough due to the combination of a steady income from their profession, and several additional income sources. Also, upwardly mobile families (maju) are within this category. In the past, people could accumulate wealth from local resources such as cattle and land (e.g. Pak Patik) but, increasingly, maju people have made their money outside the village from (trans)migration, their profession or business.

\section{The Just Enough (Cukup)}

Among the 'just enough' are those villagers who generally own some sawah, tegal and cattle, but less than the 'enough'. In general, they have access to relatively good or stable incomes or trades. Moreover, many of them are not that heavily engaged in tobacco farming, although some lease or sharecrop tegal from larger landowners, but rely on non-agricultural forms of income to finance household needs. Their houses are made from wood, or bamboo, with concrete floors, and sometimes they own a radio or a small battery-powered television. They do not own motorcycles, except for one or two families who

\footnotetext{
30 In five cases, villagers were able to gain money from migration. Among these were returning female migrants from Malaysia and a few families who followed transmigration programmes, succeeded, and sold their lands to return to the village. Not a single spontaneous migrant returned prosperous.
} 
gave way to demanding children and sold assets to buy their children one. Most of them do not produce enough food on their own fields to fulfil household needs and combine farming with a variety of other activities. Among the 'just enough' are many of the shopkeepers, owners of coffee stalls, and peddlers and small traders selling livestock, chicken, fish, or baskets. An example of a 'just enough' is Pak Has whose lands produce enough to feed his family for about six months. In addition, he is a tailor, hairdresser, shopkeeper and parttime religious teacher in the surau of his father. He and his wife have put their hope in their son who they send to a nearby pesantren (religious school) hoping he will become an important religious leader like his grandfather. An uncle of Pak Has, living near the pesantren, pays most of the expenses of the boy.

Among the 'just enough' are also skilled labourers, such as carpenters and bricklayers, and musicians. A number of Krajanese participate in the dry season in folk theatre groups (ludruk) and music (gamelan) performances all over the region. Some of these earn relatively large amounts of money from these activities, but the earnings are seasonal.

\section{The Not Enough (Kurang)}

Those who are considered 'not enough' do not have enough to make ends meet the whole year round, and have never been able to establish a stable income or trade. In normal periods, these families earn enough to make a living, but periodically, they face shortages for which they could not prepare themselves. In these situations, they have to borrow, sell things or cut down on expenses. Remarkably, the not enough have, on average, somewhat larger landholdings and cattle stocks than the enough, but these lands tend to be of lower quality. A relatively large number do not have land, but live from a good job or trade. Among the not enough are many villagers who work the land of large landowners for a share of the harvest, and who look after the cattle of others. Also, most of the wage-labourers can be found among the kurang and here also the people who migrate for certain periods of the year can be found. Due to periodic shortages and migration, they cannot always meet the demands of the gift and labour exchange economies in the village, and this makes their networks smaller and more vulnerable. Therefore, they do their utmost to keep up exchanging gifts and perform the main selamatan.

The not enough (kurang) differ from the just enough (cukup) primarily in that they lack property and a stable income. The not enough have smaller networks and fewer relations that might offer labour opportunities, information, or assistance. Moreover, the not enough generally lack the skills to engage in the somewhat better paid types of work. In monetary terms, they live just at the Indonesian poverty line. 
An example of a not enough family is the Hasan family from Mengkuara. They live with their two children in a bamboo house with an earthen floor close to the road to Pakem. In the house, a bamboo bed, some kitchen utensils, an old cupboard, a table and a few chairs, and a flashlight make up their belongings. On their tegal, they grow maize, which they mix with rice, and which provides them with food for about six months. After the maize crop, they borrow money from an uncle at $50 \%$ interest to grow tobacco. In good years, the tobacco brings in an equivalent of six months of rice, in bad years they are hardly able to repay the loans with interest. At the back of the house, a bull is share-raised for the same uncle. Every morning and every afternoon, pak Hasan goes out to cut fodder along roads and trails, on the land of his uncle, and along the river. In the dry season, he walks hours to the forest to collect fodder, or cuts edible leaves from trees in the neighbourhood. He also works in the fields of others, or in the fields of his uncle. Sometimes, his uncle gives him bamboo to plait and weave for sheets for walls (dinding) to make some money. On other days, he goes to his fields and tries to break up the rocks in his field to sell to road constructors or house builders. His wife sometimes works on transplanting rice seedlings, weeding fields or cutting tobacco. She also helps regularly in cooking and cleaning at the uncle's house in return for some rice or maize, or a meal. Sometimes, she joins her husband in going to the forest to collect fodder or firewood to sell. In slack periods, they only eat two meals a day, and skip drinking coffee or tea, smoking, and chewing betel. Sometimes, they borrow money from neighbours, the shopkeeper, or ask for a cash advance on the bull, to enable purchases. On several occasions, they have pawned or sold gold to obtain cash. A couple of times, Hasan has followed bands of men from the neighbourhood in search of work, but he was never very successful. Once he was, and he returned with some money with which he bought a radio that he then had to sell a few months later for a much lower price. In 1999, the oldest daughter of the Hasan family was married out to someone in Madura when she was 14. Madurese are among those who marry youngest in Indonesia (Jones 2001).

\section{The Poor (Miskin)}

The poor, own hardly any land, cattle, and consumer goods. They have no regular cash incomes, and cannot make ends meet. Their houses look shabby, and if their children go to school they do not have a school uniform. They live below the generally acceptable standards of living. They have small networks and, at best, a small piece of land which does not bring them sufficient rice or maize to last even a few months. Moreover, they do not have a stable income, capital or cattle, and are not sufficiently well connected to get access to the resources of others. Moreover, they lack the strength, the health, the skills and 
the information to engage in stable labour relationships. Last, but not least, they are generally regarded as not creditworthy, and can only borrow very small amounts, or only with collateral which they often do not have.

Each year they experience periods of food shortages in which they need to cut down on expenses and consume only two meals a day. They structurally lack funds for additional costs such as clothes, house repairs, and medical costs. They live below the village poverty line (below cukup) and below the Indonesian poverty line, but are able to work, and in that way do gain some income from working other people's lands. They work as wage labourers, becoming migrant workers or produce handicrafts at home. Sometimes, they perform a selamatan and try, at great pains, to stay a part of the 'decent' village families. However, they are never able to save or plan for these occasions in advance. Many of the poor turn to potential patrons hoping that they will provide them with some stable work or support. An example in this category is the Satrawi family as described in the introduction. They face regular shortages, have hardly any land and maintain social relationships with great difficulties. Regularly, there is no food or money in the house, and the children roam around the neighbourhood in hope of a free meal. Often, they end up in the kitchen of people like $B u$ Patik who offers them leftover meals and snacks.

\section{The Destitute (Kasihan)}

The 'destitute'31 are all those who permanently live far below the village poverty line. They include widows, the chronically ill and the unemployed who are virtually without land, cattle and caring relatives. The destitute have lost their pride and can no longer contribute gifts, assistance or anything else to others. Within strict boundaries of decency, they need and ask for support or assistance on a regular basis. Old and disabled people without relatives; and handicapped people not able to work, walk, see, or having leprosy; are called pitiful, or needy (kasihan), and can expect little from social relationships in terms of access to resources. However, due to their obvious vulnerability, they are entitled to some help and might receive some social assistance and privileges from the community at a daily basis. This help however remains somewhat limited and does not exceed an incidental free meal, exemption from village taxation, small sums of money or food donations, basic medical care and, sometimes, labour assistance in collecting firewood or repairing a house. In general, this category of people cannot borrow any money at shops, from neighbours or friends, and live constantly at the absolute minimum level.

31 Dietz (2012) in the PADEV research speaks of ultra-poor PADEV 2012. 


\section{Material Indicators of Wealth}

So far, in distinguishing these social classes, I have adopted an emic approach to wealth and poverty by making use of local concepts and classifications. Adopting such an approach has a number of implications. ${ }^{32}$ First, it is idiosyncratic, and will not always coincide with (but in practice it does have) an 'outsiders' categorisation'. This wealth ranking is relative and locally-based, and therefore comparison with other regions or populations is difficult. Such classification runs the risk of being particularistic and highly context specific. It might produce an adequate case study, but it can make it rather difficult to communicate with other researchers, to related fields of study, and to social policy and development practitioners. On the other hand, such a relative approach has a number of advantages since it overcomes some of the difficulties inherent to some mainstream definitions of poverty that are static and overlook the value of social relations and the social embeddedness of poverty.

In the following sections, I try to overcome the limitations of using a relative approach by relating the local wealth-ranking scale of Krajan households with more quantifiable and material indicators of class such as property and ownership of land, cattle and labour. ${ }^{33}$

\section{Sawah}

The differences and inequalities between rich and very poor are most striking if one looks at direct sawah ownership (see Table 1$) \cdot{ }^{34}$ While the rich have, on average, one hectare of sawah (while some own up to four or five hectares), the other social classes have much smaller plots: $1 / 5$ or $1 / 6$ hectares for the enough

32 See: Breman 1980, 1994, 2000; Dixon and Macarov 1998; Townsend 1993.

33 The definitions of ownership in the survey are:(1) tanah milik dan bisa pakai (land ownership where there are usufruct rights), and (2) tanah tidak milik, bisa pakai (ambil gadai, sewa, etc.) (land not owned, but with a usufruct right at the time of interview such as rented land, land under share tenancy, and land taken as pawn or collateral. Excluded is the arrangement of babunan (taking a 1/5 share of the harvest in return for labour), which in fact is not a share tenancy relationship, but a payment for labour by giving a fixed share of the harvest.

34 By direct sawah ownership I mean ownership rights ( $h a k$ milik) and use rights (hak pakai) thus including land that is de facto controlled. This includes rented land (very rare in Krajan) and land that is taken as pawn (which is quite common). These pawns sometimes stretch over several decades. In the case of sharecropping (rare), I take the use right as the proportion (usually fifty-fifty) of the arrangement as both parties are entitled to use half of the returns of the land. See also discussions on the differences in ownership rights in Nooteboom (2001). 


\begin{tabular}{|c|c|c|c|c|c|}
\hline & $\begin{array}{l}\text { Percentage } \\
\text { of total } \\
\text { households }\end{array}$ & $\begin{array}{l}\text { Average } \\
\text { sawah } \\
\text { ownership (ha) }\end{array}$ & $\begin{array}{l}\text { Percentage } \\
\text { of total } \\
\text { village } \\
\text { sawah }\end{array}$ & $\begin{array}{l}\text { Average } \\
\text { tegal } \\
\text { ownership } \\
\text { (ha) }\end{array}$ & $\begin{array}{l}\text { Percentage } \\
\text { of total } \\
\text { village } \\
\text { tegal }\end{array}$ \\
\hline $\operatorname{Rich}($ kaya $)$ & 9 & 0.97 & 53 & 2.47 & 37 \\
\hline Enough (lebih) & 10 & 0.21 & 13 & 1.37 & 23 \\
\hline Enough (cukup) & 11 & 0.16 & 11 & 0.49 & 9 \\
\hline Less (kurang) & 19 & 0.11 & 13 & 0.47 & 16 \\
\hline Poor (miskin) & 19 & 0.05 & 6 & 0.28 & 9 \\
\hline Destitute (kasihan) & 32 & 0.02 & 4 & 0.11 & 6 \\
\hline
\end{tabular}

and just enough, and 1/10 to 1/40 for the poor and the destitute. Taken together, the rich households $(9 \%)$ control more than half of all village sawah, and, in most cases, they have the better quality fields, which produce substantially higher yields than the small plots of poorer villagers. Of the destitute, two-thirds do not own any sawah at all, and often they do not even own their home lot. ${ }^{35}$

The rich own $53 \%$ of the total sawah. ${ }^{36}$ The poorest $32 \%$ of the population own only $4 \%$ of all sawah owned by Krajan villagers. ${ }^{37}$ Fig. 2 illustrates this inequality of sawah ownership by wealth category. ${ }^{38}$ Similar, but slightly less significant inequalities can be seen for dry lands.

\section{Tegal}

Although inequality in sawah ownership in Krajan is high, such irrigated rice fields make up a tiny proportion (around $4 \%$ ) of the village lands, and are not

35 One should note that most Krajan widows are ranked in the lowest category. Some of these widows had once owned land but have given it already to their children. Only widows heading an independent household were included in the survey.

${ }_{3} 6$ This does include the ownership of sawah outside the village of Krajan (mostly in Ardisaeng and some in Andung and Tamankursi (rice fields close to the Dluwang River)).

$3740 \%$ of the population of Krajan have no sawah at all, and half of these can be found in the lowest wealth category. Of the poor, $53 \%$ have no sawah at all. And of the category of the not enough, $37 \%$ have no sawah at all. In the category of just enough everyone has at least some sawah, while of the richest villagers interviewed, $11 \%$ do not own any sawah. This is because they no longer need it due to other sources of income.

38 If quartiles are calculated, the richest $25 \%$ of the survey population owns $74 \%$ of all village sawah. The poorest $25 \%$, virtually own no sawah (0.7\%). Of the 25 poorest households, only two had a tiny piece of sawah. 


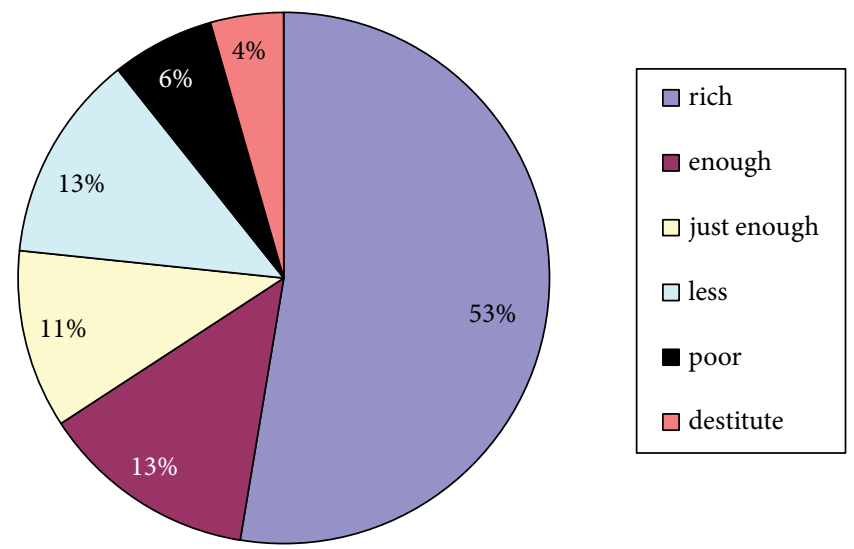

FIGURE 2 Share of sawah ownership by wealth category

the only important resource for village households. Most of the arable land (over $75 \%$ ) is tegal - generally valued at one-third of the price of sawah-and it is suitable for maize, bananas, cassava and tobacco. As most villagers mix rice with maize for their staple food, maize production on tegal is an important source of livelihood and food security.

There is a more-or-less similar unequal pattern of average tegal ownership as with the ownership of sawah (see Table 2): the rich own, on average, about 2.5 hectares and the lebih 1.4 hectares. They control about one-third and onequarter of all village tegal respectively. Also here, the poorer section of the village population owns only small plots ranging from one-tenth to one-third of a hectare. ${ }^{39}$ If there are differences between sawah and tegal ownership, then it is that the lebih have a greater relative proportion of all the dry fields in the village, and the kaya somewhat less. ${ }^{40}$ The lebih concentrate more on dry land

39 Despite these inequalities in direct ownership of land, it does not follow that the owners use all their land. Direct access to land differs slightly due to sharecropping and harvestsharing arrangements. In Krajan, sharecropping is not very important. Less than $5 \%$ of all sawah in Krajan is sharecropped, and only $11 \%$ of all tegal in the survey was shared in 1997 and 1998 for the production of the cash crop tobacco, and not for maize. These differences due to sharecropping are included in the calculations where one-half is added to the property of the landowner and the other half to that of the sharecropper. Applied to tegal, with a sharecropping arrangement for one harvest of tobacco, I counted one quarter for the sharecropper and three quarters for the landowner.

40 The enough (cukup) own only $9 \%$ of all village tegal. This can be explained by the fact that most higher educated, skilled labourers, small traders, and construction workers can be found in this category. These are less inclined to own tegal or sawah, as many in this category receive wages and can buy rice on a regular basis. These people are often more oriented 


\begin{tabular}{llllll}
\hline & $\begin{array}{l}\text { Percentage } \\
\text { of total } \\
\text { households }\end{array}$ & $\begin{array}{l}\text { Average } \\
\text { number of } \\
\text { owned cattle } \\
\text { per } \\
\text { household }\end{array}$ & $\begin{array}{l}\text { Percentage } \\
\text { owned } \\
\text { cattle of } \\
\text { total stock } \\
\text { of cattle }\end{array}$ & $\begin{array}{l}\text { Average } \\
\text { number of } \\
\text { controlled } \\
\text { cattle }\end{array}$ & $\begin{array}{l}\text { Percentage } \\
\text { controlled } \\
\text { of total } \\
\text { stock } \\
\text { of cattle }\end{array}$ \\
\hline Rich & 9 & 5.2 & 42 & 3.1 & 25 \\
Enough & 10 & 1.7 & 15 & 1.6 & 14 \\
Just enough & 11 & 1.4 & 13 & 1.4 & 14 \\
Less & 19 & 0.7 & 13 & 1 & 18 \\
Poor & 19 & 0.5 & 9 & 1 & 17 \\
Destitute & 32 & 0.3 & 8 & 0.4 & 12 \\
\hline
\end{tabular}

agriculture because it is difficult to purchase sawah, and because they are more often engaged in tobacco production.

Tegal can be pawned for one or more head of cattle which can then be sold to cover expenses. Also migrants tend to pawn their land to pay the trip to Kalimantan. They hope once to return wealthy and to get the land back. In Krajan, dozens of local terms exist that indicate different types of cattle according to the age and height of the animal. Nowadays, transfers are usually made in cash, although the pawn price is still set as the price of a cow or bull of a certain colour and age to safeguard against the risk of inflation; and, still, pawned land is often paid back in animals.

There is barely a free land market in Krajan. Villagers can only increase their acreage by taking in pawned land from families in urgent need of cash. In general, it is the rich who have cattle or ready cash available to exchange for land in pawn. However, middle class farmers (lebih) - and sometimes the better-off lower classes (cukup) - also take land (ambil gadai) for one or two heads of cattle. In this way, social mobility is possible. Notwithstanding the possibilities for social mobility are available through migration, accumulating cattle and education, there is a tendency towards a concentration of land in the hands of richer families, like elsewhere in rural Java. ${ }^{41}$ Rich families can also lose land. Among the most common reason why descendants of richer families have lost

towards the outside economy and less inclined to eat rice mixed with maize, less oriented towards investing money in land, but rather in houses, on motorbikes, and sometimes cattle. 
access to land is the inheritance system. In customary Madurese inheritance law, male and female siblings receive equal shares, whereas if Islamic law is applied, daughters inherit one-third. Children with small pieces of land were more likely to run up debts, move away, or become marginalized which force them to sell the land. In the reverse sense, only a few villagers - such as Pak Patik - were able to move from smallholder to prosperous landowner. Such families managed to save and invest in cattle and slowly build up a big herd, which then could be used to acquire pawned land or to buy land.

\section{Cattle}

Despite the concentration of land in the hands of richer villagers, not only large landowners are counted among the rich of Krajan. Traditionally, cows and bulls have been an important basis of wealth because they can be converted into other forms of capital, and because of their symbolic value. Nowadays, consumer goods such as motorbikes, cars, radios, television sets and stone houses are competing with, and replacing, the symbolic functions of cows and especially bulls.

Owning cattle is an important source of income. First, a cow or bull contributes to the livelihood of its owner and serves as a saving device. However, often it is not the owner who takes care of feeding and cutting grass, but someone else who, for this work, receives a share (usually half) of the proceeds. In the case of a cow, the tender will be given half of the cattle's offspring (mengobuarrangement), and in case of a bull, the tender receives half of the profit when the bull is sold (oanan-arrangement ${ }^{42}$ ). In the past, oanan relationships were important for status and prestige. Owners of good bulls gave them to professional caretakers who trained and prepared the bulls for aduan sapi, the Madurese bullfight. ${ }^{43}$ Today, the two arenas for bullfights are closed for religious reasons and bullfights are forbidden. Prices of bulls have fallen relative to normal market prices where traders buy bulls to be butchered.

Share-raising arrangements for cattle are very firm, and in Krajan always on a fifty - fifty basis. Because of this, caretakers cannot easily be changed; and

42 Hefner (1990: 107) notes for this 'halving' system paron. 'Under the terms of this contract, the animal tender gets to keep all the manure produced by the animal. At sale, the original purchase price for the animal is deducted from the sale price, and the remaining cash is then divided equally between the tender and owner'. In the context of upland commercial vegetable-farming in Tengger, he records a market for manure. In Krajan, I came across only one case of people selling manure; to one of the farmers experimenting with high yielding maize varieties.

43 See: De Jonge 1990; De Jonge 1994. 
caretakers of cows can use the cows to plough or for carrying goods, and usually have a say in buying or selling the animal. In practice, this means that the caretaker does indeed have around $50 \%$ of the control of the animal minus the initial value. ${ }^{44}$

The importance of cattle becomes evident from the survey that showed that $81 \%$ of all villagers ${ }^{45}$ are involved in cattle-raising; either as owners, or as tenders. Only elderly widows and some of the destitute, as well as households from the 'higher middle-class', do not raise cattle for physical, organizational, or social reasons. ${ }^{46}$ Thus, nearly every Krajan villager who is willing and able either owns or cares for cattle, but in no sense do they all have a more or less equal share. As with land tenure, property rights over cattle are very unevenly distributed, as Table 2 shows. While the rich owned on average five cows or bulls, the rest no more than one or two. As in land tenure, the rich owned nearly half $(42 \%)$ of all cattle, while the lebih and cukupan owned one-quarter, leaving the poorest classes (miskin and kasihan, $51 \%$ of the population) with control over $17 \%$ of the village livestock.

Considering only the actual ownership of cattle is misleading as figures will then be distorted by the fact that most of the richer villagers do not look after any cattle themselves, and no-one can tend more than two adult animals by himself. Poor relatives, neighbours or friends of cattle owners, look after the other animals, in return for half of the profit or offspring (oanan or mengobu), giving them thus significant control. If we include the cattle that are cared for by share tenants, the distribution is less skewed. Then it turns out that most households have at least some control over the proceeds of cattle - if they

44 Control of cattle is calculated as actual control: the sum of the number of owned cattle, owned cattle but share-raised by others ( 0.5$)$ and not owned, but share-raised for others (0.5). The number of controlled cattle indicates the number of cattle whose proceeds (profit, offspring, manure) are available to a household. The manure is used by the tender.

45 This is a high figure, but not unusual in upland farming systems in the Eastern Salient. Compare with Hefner (1990: 106) who shows for the Tengger that in the midslope area two-thirds of the population own or share-raise cattle. One-third of the landless, and about $40 \%$ of the landless and small peasants, are tending cattle. According to Hefner, cattle raising is less profitable than the production of commercial vegetables. In Krajan, where these opportunities are scarce, cattle is one of the few cash generating activities.

$4612 \%$ of these $19 \%$ not caring for cattle are old widows who cannot for physical reasons, widows supported by children, and destitute villagers could not get access to a cow. The other $7 \%$ are mostly upper middle class villagers (cukup and lebih) with other, more profitable, work opportunities, or seasonal migrants making it impossible or not so necessary to care for cattle. 
want it. The three poorer classes - who amount to two-thirds of the population - on average, control the proceeds of about 0.7 animals per household, amounting to nearly half of all cattle in Krajan. Presented in this way, the distribution of control over cattle turns out to be more equal than for other resources and a means of levelling inequalities somewhat. ${ }^{47}$

Finally, it should be noted that the ability to tend cattle relates to the ability to gain access to grass. Here I cannot elaborate at length on the specific difficulties in obtaining fodder in the dry season, especially for poor families, but, in general, grass can be cut along roads, trails, rivers, and in the forest. Night-time thefts of grass do occur, and sometimes competition over grass is so fierce that fights occur. Those who own sawah or tegal often plant elephant grass along the dykes and ditches of their fields, others are dependent on the goodwill of landowners. In many cases, tenders have some rights to the grass along the ditches of the owner of the animal. In addition, taking harvest shares give rights to the grass along the edge of fields and the crop leftovers. In general, the less resources a household owns, the more difficult it is for them to obtain grass of good quality (except for those living near the forest).

\section{Consequences of Inequalities: Food Production, Self-Sufficiency, and Access}

What does this inequality in landownership mean for the food production of households? During the survey, I asked each head of the household - and often the wife - how many months the household would be able to eat from the production of their own, rented, and sharecropped fields. The results in Table 3 show that differences in self-sufficiency between the social classes of

\section{TABLE 3 Number of months of self-sufficiency in food}

\section{Number of months self-sufficient}

\begin{tabular}{ll}
\hline Rich & 9.8 \\
Enough & 8.4 \\
Just enough & $7 \cdot 5$ \\
Less & $5 \cdot 1$ \\
Poor & 2.7 \\
Destitute & 1.6 \\
\hline
\end{tabular}

47 If quartiles are calculated, the inequality is still striking. The upper $25 \%$ control $48 \%$ of all cattle proceeds, while the lower $25 \%$ controls only $10 \%$. 
villagers are almost as sharp as in land ownership. Through share cropping arrangements (babunan), even the poor are able to gain some income in kind, but inequalities remain.

An important fact hidden here is that richer families do not mix much maize with their white rice, and so finish stocks more quickly, while poorer families generally mix in more maize with their rice to reduce costs and prolong stocks. Additionally, feeding agricultural labourers puts a strain on the food stocks of especially large landowners. Poorer villagers, especially those in the 'cukup and miskin' categories work regularly as wage labourers in the fields of others, and save their own food stocks by eating frequently at other people's houses, while they rarely employ and feed labourers themselves. ${ }^{48}$

The poor and destitute are worst-off as their own supplies last for no more than 1-3 months - a supply which hardly stems from their own land (of which they have virtually none) but from sharecropping participating in harvests or gleaning the leftovers after harvest, from roots and tubers which they collect on wastelands, and from food given to them by children or neighbours.

The data from Krajan show that ownership rights are vary unevenly distributed, with the richest class owning about one half of the village's main resources: rice fields, dry fields, and cattle; while the poor own only tiny plots at best. To some degree, share-tenancy on village land, and share-raising of the village cattle, provides the poorer classes with at least some access to resources. Sharing arrangements thus mitigate somewhat local inequalities, but the overall picture of a small number of households in firm control of the village economy remains. The poorer households - who together make up two thirds of the village - have to rely on other sources of income to survive. An obvious source for the property-less is income earned from working for other people. The next section will discuss the different labour arrangements in more detail.

\section{Labour and Work}

Some households earn incomes from a variety of sources, other are dependent on only a few crops or sources of income for their livelihood. Essentially, for those poor who are healthy and able-bodied, the main resource they have is selling their own labour. By working they secure income, and they also maintain their social networks which are, as I will explain, crucial for their survival in the

48 The classes described are not tenure classes, but social classes and that lebih and kaya also include rich people who are not dependent on farming, such as traders, returned migrants and teachers. 
village. Access to employment, however, is not easy and can never be taken for granted. People try hard to obtain work, and they do this in many different ways.

Although the land and cattle are very unequally distributed in the village this does not mean that the landless and small farmers completely lack access to land. Villagers with little or no land can get access to a part of the harvest by sharecropping or taking harvest shares. Sharecropping (paronan ${ }^{49}$ or paron Mad.), a 50-50 sharecropping deal of sawah in Krajan seldomly occurs. Only about five Krajan villagers give their sawah out in sharecropping. Some $75 \%$ of the poor families in Krajan are involved in babun ${ }^{50}$ (Mad.), a system of payment in kind through harvest-shares of friends, neighbours, patrons and relatives. There are basically two types, babun (Mad.) and beton (Mad.). In babun arrangements, people receive a one-fifth share (maize or rice) in return for their labour; and this arrangement lasts in principle for one cropping season. Beton arrangements are long, often life-long, arrangements with the same share. Both arrangements, babun and beton, are only used with food crop cultivation. In addition to the harvest share; two meals, coffee and cigarettes are provided during workdays. The babun share of one-fifth has to be divided among the workers. Sometimes, the owner of the land is included if he has worked alongside the labourers. In the case of larger landowners, this is seen as greedy and indecent, as it means a lower share for the workers.

As sharecropping through babun contracts is common practice on the fields of the large landowners, these contracts imply some kind of redistribution albeit that, in the end, the landowner benefits most as this payment-in-kind covers all his labour expenses. ${ }^{51}$ Given the fact that the richer classes (kaya and lebih) together own $66 \%$ of all sawah and $60 \%$ of all tegal, and that the standard

49 Paronan refers to the practice where paron is the root word (comparable with maro in Javanese). In the following, I will give the root words only (and leave out $k e-\ldots-$ an constructions which are used to refer to the practice of and the deal itself).

5o Babun (beton in case of long-lasting arrangements) is a Madurese term for wages in kind (in rice or maize) as a 1:5 share of the crop in return for labour. In the case of old rice varieties and maize, the workers chose one bundle out of every five. Compare with the Javanese word bawon, which means literally: '(1) a share of the rice harvest received for one's services during the harvesting [...] (2) a certain size bundle of newly harvested rice plants' Horne 1974. It is the best part, or the biggest bundle. Babun should not be confused with the Javanese bawon, the latter of which is generally referred to as a harvesting arrangement. Babun is comparable with the Javanese kedokan arrangement Van der Kolff (1937); Wiradi (1984) but differs because the share in Krajan is always fixed (1:5). Babun applies to old and modern rice varieties in the same ratio (and also often to maize).

$5^{1}$ Except for costs on meals (one or two per working day), coffee (one glass), and something to smoke (tobacco or one or two kretek cigarettes). 
workers-share is $20 \%$, this implies that poorer villagers, through their babun work, acquire access to $13 \%$ of the sawah produce, and $12 \%$ of the tegal insofar as food crops are concerned (tobacco is not cultivated in babun contracts).

As keeping cattle and food crop production are closely related in Krajan, gaining access to fields by taking on babun also means access to fodder. Babun workers need to have cows at their disposal to plough the fields. On some rare occasions, people can get a babun contract without having a cow; when the worker is young, recently married, or when a cow is still in training, or when one's cow has recently died. While, in the case of beton, the worker has to turn up when summoned, in the case of babun, workdays can be negotiated. If one of the workers is not able to come, he can send someone - usually a child or relative - to replace him. If he does not, he will lose his right to a share of the harvest, or his share will be reduced. Moreover, the arrangement is part of a patronage relationship in which the landowners often also give small loans, pay part of funerals, give gifts, and the like.

Many villagers favour being paid in babun over receiving a day's wage because of these reasons. Moreover, the average returns from babun are significantly higher than those from wage labour. On average, babun workers earned about 3 kilos of rice for a day work. Further, it is not only the cash value that counts, villagers prefer wages in kind over those in cash because they can store the rice and maize and thus secure sufficient food for the coming months. 'Money cannot be saved', villagers often commented.

Villagers make strategic choices when opting for wages in kind instead of cash. They also say that they like to get several babun contracts because this enables them to spread risks over several fields (different locations and altitudes) or over several rice varieties and over several bosses. However, the unstated main reason is also that often wage labour jobs are very difficult to get. In years when many harvests failed because of diseases and irregular rains, people say many villagers even more strongly preferred babun, a way of saving 'in others'. In fact, they are building up social capital, and labour arrangements such as babun are a crucial investment for creating and maintaining solid ties between workers and landowners.

Babun arrangements contribute an important element to the food security of poorer Krajan households because they contain a firm right to a fixed share of the harvest. Some small farmers spread risks by sharing their own land through babun while, at the same time, taking up babun in the fields of others. To an outsider's it might have seemed more profitable to work their own land alone, to minimize labour costs and reap all the harvest. However, people consider working together on land in small groups to be more efficient, and to 
spread risks as it provides access to other plots of a different quality than their own. Moreover, it offers access to knowledge and information, and helps to finish the work more quickly. Again, the main reason is that it extends social networks and thus the chances of getting help when it is needed.

Not everyone can get a babun contract as one needs to have a good relationship with the owner. If one gets babun then social relationships with the employer can become stronger over time and the employer can become a kind of friend. Satrawi described this dual advantage of babun by using a wellknown Madurese saying: 'A friend can become a relative, while a relative can turn into an enemy'.52 By working one makes friends, and therefore labour contracts with large farmers are highly desirable. For him, this is the major reason that he prefers good relationships with many people and wages in kind, over a cash wage.

Beton, and to a lesser extent babun contracts are often a part of patron-client bonds. Beton workers are supposed to do other jobs for the landowners, and also their wives and children might help around the house or in the kitchen of the landowner, and help at the preparations for a selamatan. Patron-client relationships offer many benefits in getting and guaranteeing access to resources. As Hefner described for the Tengger mountain area: 'Many poor villagers seem to prefer the loss of personal freedom above the insecure way of living of those who have no access to this kind of tied land-labour relations' (Hefner 1990:80). It is not just a 'fear of freedom', but mainly because patronage relationships and friendship are the most obvious ways to gain access to land, cattle or work, and to be eligible for help in times of need: in short, to survive in Krajan.

Payments in kind, like harvest shares, meals, drinks, and cigarettes have been common all over Java, but locally there can be differences in the way these payments are made. In Krajan and surroundings, the one-fifth harvest share for babun is fixed, and according to villagers it has always been so. For new varieties of maize introduced in 1998 however (which are regarded as a cash crop, rather than a subsistence crop), a share of one-sixth or even oneseventh was sometimes used because landowners say that their expenses have gone up, and that harvests are bigger anyway so that, in the end, the workers will still receive the same amount of rice or maize..$^{53}$ Though common across

$5^{2}$ Madurese saying: 'Kancah bisa detdih taretan, taretan bisa detdih mosoh', (teman bisa jadi saudara, saudara bisa jadi lawan).

53 Babun is found across the whole district of Pakem, Wringin, and Besuki, and probably in the whole of Madurese East Java. In Javanese Java the very similar arrangement of kedokan is generally found Van der Kolff (1937); White and Wiradi (1989). 
East Java, babunan contracts come in several shapes and there are minor variations between villages and hamlets, and also between crops. Apparently, babun is interpreted, negotiated, modified and adapted according to local circumstances and conditions. Over the years, there seems to exist a clear connection with population pressure and researchers in the past has explained the size of the share by population pressure, as a levelling and redistribution arrangement, as an exponent of the moral economy, and by the ability of the poor to claim a share of the rich. Many of these writers expect the disappearance of these arrangements after commercialisation and a breakdown when too many people migrated. Both did not happen in Krajan. The arrangements turn out much more flexible and subject of negotiation than often assumed.

\section{Local Variations in Labour Arrangements}

The hamlets of Dluwang and Pakualas are the most remote, and for a long time the most isolated and, probably, the most closed communities. They belong to the most recently settled parts of Krajan and the fields were cleared only one or two generations ago. The two hamlets are therefore relatively homogeneous; including from a religious perspective since most inhabitants belong to a single orthodox group belonging to one kiai represented by organizations such as NU (Nahdatul Ulama) and Ркв (Partai Kebangkitan Bangsa). ${ }^{54}$ Land is relatively fertile and abundant, and people use few chemical inputs as cash is scarce in these two hamlets. However, given the remote location, labour is also relatively scarce as not many workers from elsewhere go to these hamlets looking for work. Mutual labour arrangements are therefore more important than in the other hamlets and the share of babun is larger, up to $25 \%$.

Harvest arrangements vary depending on crop, place, type of community, culture and form of ownership. Moreover, in upland areas, many of the traditional arrangements have survived the agricultural reforms of the New Order regime. This also questions the linear, political economic expectations that farmers will increasingly be dispossessed and only a few large farmers will remain. Reality is much more complex. In the higher areas of Krajan, old longstalk varieties are often grown for economic, social and cultural reasons. These varieties require time-consuming manual ear-by-ear harvesting. Due to this increased workload, the harvesters receive an extra bundle of rice $\left(1.5^{-2.5} \mathrm{~kg}\right)$ on top of their babun (kedokan) share. Usually, those who planted the rice have the right to harvest. Harvest shares also vary accordingly to social closeness: it is often only the wives or female relatives of kedokan-takers who are accepted

54 In these hamlets, over 90\% voted for the Ркв during the last elections. In Krajan proper, Mengkuara, Sayuran, Wriningkurung and Morsungai, the majority voted PDI-P. 
as harvesters. The free access, as described by Geertz (1963) and others, ${ }^{55}$ in lowland Java before the Green Revolution, where villagers could harvest without personal invitation, has never existed in Krajan. Who is invited depends on the labour arrangements and the preferences of the farming family; if they want to tie certain labourers to them, they will only invite those labourers. ${ }^{56}$ Free access to harvests applies only to 'new' IR varieties of rice that can be cut with the arit, the Madurese sickle, and threshed in the field. Here, harvesters help in cutting and threshing the rice and get a share of the straw for cow fodder. Sometimes these uninvited harvesters receive some food, or something to smoke. In the dry season, when fodder is scarce, such harvests are overwhelmed with people trying to get a bundle of straw. Babun workers, also in need of animal fodder, often try to keep the day and time of the harvest secret, or start harvesting in the middle of the night or very early morning to be ready before dawn and be able to take all the straw home. Thus, the poor exclude the poor.

Unlike in rice cultivation, in tobacco farming tegal is share cropped, albeit on a seasonal basis only. Almost one in seven households that are engaged in tobacco farming share their crop. Sharing contracts for tobacco last one growing season and, generally, the costs of land and inputs are shared, or landowners provide the money and others the labour. Essentially, it is a way to control labour as the worker is not free to choose when and where to work. Further, it is the middle-level farmers who have their tobacco sharecropped by others. This means that the tobacco sharecroppers engaged in sharecropping are generally the 'just enough' (cukup) and the 'not enough' (kurang) villagers. The poorest villagers (miskin and kasihan) are excluded from these sharecropping

55 Abdullah and White 2006; Hart, Turton and White 1989; White and Wiradi 1989; Wiradi 1984.

56 As noted previously, the Madurese word babun might seem similar to the Javanese word bawon but the arrangements are different. Bawon refers to the open harvest of old, long grain, varieties of rice which have to be harvested by the labour intensive ani ani method. Babun refers to a one-fifth share of the harvest plus meals in return for all the work involved. It can be applied to the harvesting of rice and maize. It can probably best be compared with the Javanese babon, which refers to the choice of the biggest bundle after the harvest Hüsken. It is a kind of a mix of the Javanese sambatan (mutual help) and pakehan (bawon share of harvest in return for planting and harvesting) Van der Kolff (1937). According to Van der Kolff: (1937:15), these forms developed into kedokan in response to increasing population pressure. In the original form, workers received larger shares and had to do less work. Van der Kolff notes one-quarter shares of the harvest, without soil preparation before planting, in 1936. Due to population pressure, shares have decreased. This shows that the arrangements are fairly universal and can survive over many generations, but that the contents of the arrangements are more flexible. 
arrangements as they cannot afford the costly inputs and are reluctant or unable to take on the huge risks involved in tobacco farming. The richer villagers, who have enough land, cash or credit facilities to grow tobacco themselves, prefer to manage their own crop and reap all the profit.

\section{Arrangements for Cattle}

In securing a livelihood, cattle have similar functions as land but the ownership of cattle is much more widespread than that of land. According to many of the poor, share raising cattle is productive, secure and provides status. Although the actual ownership of cattle is nearly as unequal as that of land, there are two arrangements for share-raising (ngobu $u^{57}$ Mad. and oanan Mad.) that offer many poor villagers access to some relatively stable income. In the first arrangement, the caretaker gives the first calf born to the owner and is allowed to keep the second. In the second arrangement, only the profit is shared. The caretaker has total control and responsibility for the cattle. They can be used for ploughing and preparing rice fields. These share-raisers are thus able to engage in babun contracts and gain access to land as well as an opportunity to save (in the form of cattle) and build up property. Many villagers share an ideal of owning their own herd, but very few are able to succeed and build up a stock of cattle. For the destitute, who do not own any assets, this is particularly problematic as any calves they receive as payment for their work often have to be sold soon after they are born to repay debts or cover household needs. Sometimes they even sell their calves before they are born at a much lower price. About two dozen Krajan families from the fourth and fifth categories have managed over the last fifteen years to rise from partakers in ngobu to independent cattle owners.

While sharing arrangements for cows and bulls are crucial to the income of poor villagers, cattle serve as a saving mechanism for nearly all the households in Krajan. The question is if this arrangement protects or exploits the poor. It has a dual nature, and can be seen as doing both. Those without access to

57 Leunissen (1982:152/204) mentions the Madurese word $n g o b u$ for an arrangement where seed (such as peanut or soybeans) is borrowed under the condition that half of the produce will be returned to the owner of the seed. I did not come across such an arrangement in Krajan for seeds, only for cattle and chicken (the caretaker takes half the offspring). Koning Koning 2001 describes a cattle-sharing arrangement in her paper on Central Java and mentions gaduh: 'for goats and cows the gaduh system (taking care of the animals owned by someone else) is practiced. In case a goat has two young, one of the young is for the caretaker who can chose which animal he wants. Usually the male animals are preferred as these grow faster and have a higher value. For cows in Krajan a similar system is used but with more strict rules as the price of cows is much higher' Nooteboom (2001). 
cattle can face serious difficulties when they need money. This applies in the first place to widows, the elderly and the sick who cannot collect fodder, and thus are unable to gain a shareholding contract. It also holds for the destitute (kasihan) of Krajan of whom $36 \%$ do not own or share-raise cattle, they are simply not trusted and not considered sufficiently reliable to care for cattle. ${ }^{58}$

\section{Getting Rich in Krajan: (Social) Mobility}

Where the Patik family was able to rise from rags to riches by slowly accumulating property through acquiring village resources, they reflect no more than ten per cent of the villagers who have been able to significantly improve their living conditions. There are essentially four upward trajectories in Krajan to escape poverty: through the accumulation of cattle to then buy land, through education, through trade and through migration. The production of cash crops such as tobacco, chillies or, increasingly, timber is only available to those who have sufficient land.

During the last four decades, another 10\% have slowly slid from a relatively prosperous rural livelihood into poverty. They include the Satrawi family living beyond their means, and also families who lost fortunes in tobacco trade and speculation, through gambling, divorce or through sheer misfortune and loss of productive family members. It is often a combination of the above that lead to families falling into poverty.

The majority of the relatively affluent families with land and cattle have been able to remain prosperous and almost all of the old landed village elites have been able to add to their land and their number of cattle. Moreover, they occupy important positions in village politics or religious affairs, and they thrive on the new opportunities Indonesia has to offer. They trade in tobacco, give loans on credit, transport goods to nearby towns, trade in the city and allow their children to study. They maintain good connections with the outside world through religious networks, politics or trade. These families are the drivers behind the slow but steady process of land ownership becoming concentrated in ever fewer people.

A large majority of the Krajan population, almost 80\%, have become slightly poorer or slightly richer or stayed in their wealth class. The basic agrarian

58 Thirty-six per cent of the kasihan of Krajan (including widows) do not own any cattle whereas $64 \%$ do, or share-raise cattle, and in that way have access to some income and stability. Of the miskin, $21 \%$ do not own any cattle, while all kurang have or at least shareraise cattle. 
structure of unequal land ownership and low paid labour has not changed. Over the last four decades, the proportion of poor villagers has neither increased nor fallen, while the group having just enough has also not grown. Over the years, tobacco prices have slightly improved, but not soared, rice and maize production in this dry land area has not increased and almost no new cash crops have been introduced. The only exceptions being the newly established state-owned coffee plantation and the growth in planting fast growing trees such as sengon (Paraserianthes falcataria), and mahogany (Swietenia macrophylla). Wages in the coffee plantation are low and the growing of trees will benefit only those who have firm access to land.

The only other way to escape the constraining village structure has been migration. It is very hard to reconstruct migration figures over the last four decades as no records are kept and village statistics are unreliable. Through life histories and through systematic surveying and explicitly asking about the migration histories of the surveyed families, their neighbours and relatives, a basic picture emerges. Migration from Krajan has slowly increased since the 196os. In the beginning, it was only the lower middle-class families who had enough capital to send one or more sons away to find work. They found seasonal work in the region in tobacco, coffee and sugar cane, and some settled in the area between Bondowoso, Jember and Banyuwangi. A few found work in the towns of Bondowoso and Jember as craftsmen. After the mid-1980s, some Krajan families were able to join transmigration projects to Sumatra and Kalimantan (Madurese from Madura were never part of transmigration programmes), some of them returned, but the majority of these families simply 'disappeared' and connections with the village ceased. At the end of the 1980s, labour recruiters increasingly found the village and recruited labourers from the poorest families to work in Kalimantan. From this time onwards, outmigration increased rapidly with 100 people a year migrating, or 3 to $5 \%$ of total village population between 1987 and 1997 (estimates of village officials and survey). During this period, young women first started to work as domestic helpers in town, but numbers remain low until today as women tend to marry very young and Madurese values are not in favour of letting women travel, work or migrate alone. In 1997, around five per cent of Krajan villagers had a family member working outside the village. Today this has risen to more than $10 \%$.

Many young men try to find their luck beyond the vicinity of the village. Young men migrate to work for a few years in the oil palm plantations of Kalimantan, in construction or in brick kilns or stone quarries, while women stay in the village, care for cattle, work as agricultural labourers in the tobacco industry or find a job in town. Today, increasingly, also women move out of the village to find work. In Krajan, this did not happen before the end of the $1990 s$. 
This chapter has highlighted the poor agricultural resource base of Krajan, one of the many Madurese villages in Bondowoso district. It has dealt with existing inequalities, poverty and ways of accessing resources in Krajan. With a focus on inequality and access, rather than on a precise poverty line delineating incomes, I have shown the structural inequalities among large groups of the Krajan population both in direct and indirect access to resources. Inevitably, this chapter therefore dealt with the old, but still relevant, theme of widespread inequality and poverty in rural Java. ${ }^{59}$ Starting from an insider's viewpoint, it shows the continuing structural gap between rich and poor by taking local definitions of rich and poor.

The crux of the matter in understanding poverty is not the lack of income as expressed by a poverty line, but the lack of and exclusion from access to resources, and the realisation that poverty can be temporary and dynamic. Rather than measuring income, the analysis of direct and indirect ways of gaining access offers a better picture of inequality in Krajan. We saw that the large inequalities in direct ownership of sawah, tegal and cattle are reduced by up to $20 \%$ by four factors. Firstly, the property of richer villagers is shared through sharecropping, share harvesting and the share-raising of cattle. Secondly, most labour arrangements for working on the lands of richer villagers include the provision of meals, thus reducing the pressure on the household food stocks of labouring families. Finally, sharecropping arrangements are primarily about social relations. Workers are often entitled to social assistance in times of need. Nevertheless, even after these adjustments to the apparent inequality in access to resources, the gap between rich and poor is still astonishing. A small minority, of about $9 \%$ of all households, controls over half of the village's resources of land and cattle, while over $60 \%$ of the villagers face hardships in securing basic needs on a regular basis. This final figure has hardly fallen in recent decades: the only way out is to move out. Further, the figures show a tremendous divide between the haves and the have-nots. These inequalities are widely reproduced in the power relationships between rich and poor villagers, so maintaining and perhaps even enhancing the inequalities. It is from this unequal situation that many of the poorer people, and often not only the poorest, have decided to try their luck in Kalimantan.

59 See for debates on poverty in Java among others: Alexander and Alexander 1982; Breman 1980, 2000; Edmunson 1994; Hüsken; Hüsken and White 1989; Jellinek 1991; Levinsohn, Berry and Friendman 1999; Singarimbun and Penny 1973. 